\title{
La historiografía mexicanista y la hacienda colonial. Balances y reconsideraciones
}

\author{
Frédérique Langue * \\ Centro National de la Recherche \\ SCIENTIFIQUE FRANCIA
}

Aún cuando existen revisiones bibliográficas como las de François Chevalier o Eric van Young, en escasas ocasiones se ha tratado el tema de la hacienda novohispana en su globalidad. Esta reinterpretación historiográfica sobre el tema abarca estudios recientes, intenta ampliar su perspectiva al proponer un enfoque distinto, tal como la relación con otros ramos de la economía y de la sociedad colonial (minería).

L as interpretaciones recientes del "pasado mexicano", -originadas a veces por preocupaciones presentes, de índole ideológica- han despertado no pocas expectativas y debates. Una de ellas, iniciada hace unos diez años, consiste en cuestionar el modelo imperante en términos de historia económica y social que se le aplicó a la gran propiedad. Esta tiende por lo tanto a relativizar-el papel de la hacienda mexicana en cuanto microcosmos autosuficiente $y$

* Agradezco a Georgina Moreno Coello su ayuda en la revisión final de este trabajo. ocasionalmente "autárquico", tal como se llegó a definir por ejemplo en el llamado "siglo de la depresión". De cierto modo, estas reconsideraciones del pasado histórico corren parejas con una revalorización del periodo colonial, fundada, como lo subraya $\mathrm{E}$. Florescano, en un rescate documental excepcional y, a nuestro parecer, en una ampliación decisiva del llamado territorio del historiador, más abierto en adelante a los aportes de disciplinas afines, a propuestas metodológicas renovadas, algo más sistemáticas en sus inicios. De tal forma que la caracterización de las haciendas novo- 


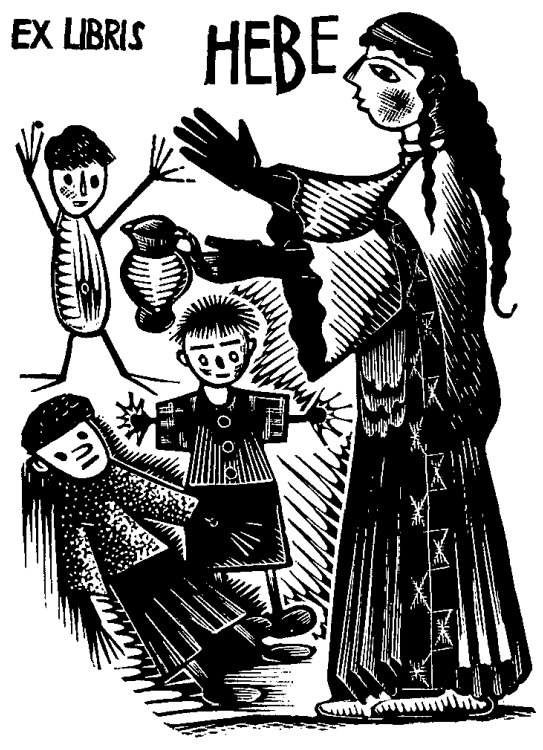

hispanas que se hace ahora, poco tiene que ver con la leyenda negra que se les aplicó anteriormente. En esta perspectiva se rechaza la denuncia, disfrazada de estudio científico, del "feudalismo" contrapuesto a unas formas halagadoras de capitalismo incipiente y "moderno" por esencia. ${ }^{1}$

Al análisis institucional propiciado por unos cuantos pioneros y a los intentos de interpretación en términos sociales (en cuanto enfoques dinámi$\cos$ ), siguieron los debates alrededor de la naturaleza "feudal" o "capitalista"

\footnotetext{
${ }^{1}$ Florescano, Nuevo, 1992. Sobre el "diagnóstico feudal", véase el análisis de Chiaramonte, Förmas, 1984, 1a. parte; Serrera, Guadalajara, 1977.
}

de las estructuras productivas, así como de las distintas formas de dependencia. En este contexto se inscribe una de las primeras aproximaciones a la institución económica y social que constituye la hacienda y el latifundio desde la perspectiva de la historia social, de la historia de las mentalidades y representaciones. Después de la obra de F. Chevalier, y del trabajo poco conocido de Herbert Nickel, y pese a la publicación de varios trabajos novedosos cuya perspectiva se benefició de los intercambios mantenidos con las ciencias sociales -me refiero en especial a unos cuantos avances que lindaron con la historia de las ideas, de las creencias, de la vida cotidiana y de la civilización material, de la demografía histórica y de las mentalidades- ${ }^{2}$ y salvo contadas excepciones de enfoque regional (W. Taylor, R. M. Serrera, E. van Young), en la mayoría de los casos, no se han llevado a cabo de una manera sistemática y comparada los estudios en torno a las haciendas novohispanas.

Tampoco se ha profundizado mayormente en ese fenómeno esencial que John Tutino ejemplifica refirién-

\footnotetext{
${ }^{2}$ Young, "Historia", 1992, p. 131; Nickel, Soziale, 1978. Este trabajo fue el primer intento sistemático por comprender el funcionamiento de la hacienda en su vertiente social, con especial referencia a la región de PueblaTlaxcala. Taylor, Drinking, 1979; Farriss, Maya, 1984; Pescador, Bautizados, 1992; para citar tan sólo las obras más representativas de esta renovación de los enfoques. En esa perspectiva, véase también la recopilación de Kicza, Indian, 1993 y las obras "clásicas" de Brading, Mineros, 1975, y Haciendas, 1978; Bakewell, Minería, 1976, o Wobeser, Hacienda, 1988.
} 
dose a una "etiología de la sociedad señorial y patriarcal que giraba alrededor de los grandes terratenientes en muchas partes de México". La hacienda sigue siendo un recuerdo del pasado, una suerte de anatema asociado a la corriente liberal que constituye para muchos intérpretes de la historia nacional la caracterización de Molina Enríquez (la hacienda no es negocio...) o al contrario, lleva al convencimiento de que se inserta necesariamente en una dinámica de intercambios exclusiva de cualquier otro tipo de comportamiento que pueda contrastar o incluso "chocar" con la modernidad ostentada por los defensores de esa última aproximación al tema que nos interesa aquí.

Ahora bien, hay que señalar que últimamente, se ha renovado el interés por la historia agraria (especialmente por lo que se refiere a los siglos, $\mathrm{xTX}$ y XX) y de modo más específico por la hacienda y su tipología, en estudios funcionalistas, marxistas o sociales: la hacienda dejó de ser un mundo autárquico, por no decir familiar y clánico para adquirir todas las características de un espacio donde se desenvuelven determinadas relaciones sociales, con los correspondientes grados de conflictividad o al contrario, con la expresión de sociabilidades antiguas, los cuales van predominando según la opción ideológica del intérprete. Estas interpretaciones y estas divergencias, no apuntan sino a una evidencia: la hacienda no es una; su diversidad y su dualidad es incluso parte integrante de su definición, de ahí el reto que constituye cualquier aproximación a su estudio y la impor-

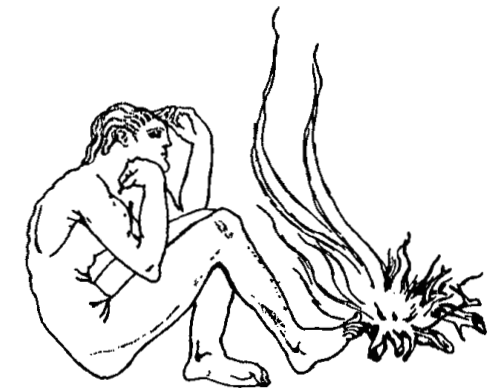

MRA ARMANDOCCHMOLL dR EX-LIBRIof

tancia que adquiere en este contexto de fuertes connotaciones ideológicas el regreso a los estudios regionales para sentar más adelante las bases de una formulación global. ${ }^{3}$

Si bien se han realizado estudios muy valiosos acerca de las relaciones que estas unidades de producción establecieron con el llamado mercado interno (especialmente con las ciudades) y más adelante con la corriente general de los intercambios, de su funcionamiento interno (factores internos de producción, tierra, mano de obra, capital invertido), de la integración de las actividades económicas, del movimiento de los precios, de las relacio-

${ }^{3}$ Sobre lo decisivo que resulta ser el enfoque regional y los modelos interpretativos existentes, véase la muy completa antología de Pérez, Región, 1991. 
nes con las comunidades indígenas, de la naturaleza del crédito que proporcionan en esta sociedad colonial, la Iglesia, los comerciantes y unos cuantos "banqueros de la plata"; en otros términos, acerca de la lógica interna que preside a las estrategias "capitalistas" desarrolladas por los dueños de estas haciendas representativas de una agricultura comercial; en cambio, poco o muy poco se ha dicho acerca de los comportamientos que no estuviesen relacionados de manera directa con la búsqueda de la modernidad ejemplificada a través de la rentabilidad de estas entidades económicas. Se descartó por lo tanto el aspecto social de ésta, en parte por la dificultad inherente a este tipo de estudios (son escasas las fuentes que permitan analizar detallamente la vida interna de una hacienda, ya sea de los peones o bien de los capataces y de los dueños, además del ausentismo que se les achacaba a éstos en la historiografía especializada), y por el hecho de que hay que realizar una lectura distinta incluso de las fuentes consideradas tradicionalmente como fuentes económicas (por ejemplo las cuentas de Real Hacienda, cuyo interés para el historiador pasa de lo meramente económico). Está por demás insistir en las modalidades de esta consolidación de las fortunas y en las estrategias sociales que convierten a unos cuantos personajes en verdaderos empresarios. Es el caso, por ejemplo, de los "mineros capitalistas" que describen precisamente los documentos de la época. Son al mismo tiempo grandes mineros, hacendados, comerciantes y, ocasionalmente, banqueros prestamistas, tales como los que tuvimos la oportunidad de estudiar para la región de Zacatecas. La ascensión social culmina en estos ejemplos con la otorgación de un título nobiliario. ${ }^{4}$

Hablar tan sólo de un sustento económico, de una base económica que se asiente en las haciendas nos parece por lo tanto más adecuado, y más cuando se acentúa, conforme vamos avanzando en el siglo XVIII, el aspecto comercial de las mismas. Los estudios regionales nos permiten, sin embargo, relativizar y sobre todo afinar esta percepción. De la misma manera nos llevan a realizar una aproximación a los fenómenos olvidados que son en lo social y en lo jurídico (en lo jurisdiccional incluso) la permanencia de modelos culturales de raigambre hispánica que tiende a pasar por alto la imposición de una especie de historia oficial de índole economicista: tal es el caso en especial de los vínculos de tipo señorial que afloran constantemente en el quehacer cotidiano de los habitantes de una hacienda, en las relaciones de reciprocidad que se dan en su ámbito jurisdiccional y en la persistencia de un "estilo de vida" al que intentan aproximarse - hay que destacarlo- los estratos inmediatamente "inferiores" de la sociedad indiana, así sea la burocracia imperial como lo subraya Michel Bertrand, en un estudio reciente que contempla la trayectoria social de los oficiales reales en los siglos XVII y XVIII, o los recién llegados a Nueva España, comerciantes enriquecidos, a veces, en el comer-

\footnotetext{
${ }^{4}$ Langue, Mines, 1992.
} 
cio transatlántico o transpacífico, también en el siglo de las Luces. ${ }^{5}$

De lo anterior se deriva la propuesta de una visión de la hacienda en su globalidad, así como un balance historiográfico de los estudios realizados al respecto, hasta ahora. Hay que recordar en ese aspecto que no se puede disociar lo económico de lo social, como lo puntualizó en otros tiempos Ángel Palerm. De la misma manera que no se puede considerar a los distintos ramos que conforman la economía colonial independientemente unos de otros como lo subrayó el ministro de Indias, José de Gálvez, quien veía en la minería el principio organizador de la economía y de la sociedad local.

El funcionamiento de las grandes haciendas de campo en las zonas mineras (Zacatecas, Guanajuato, entre otros) sólo cobra sentido si se le relaciona con un conjunto de actividades que van de la minería (minas propiamente dichas y haciendas de beneficio de metales, a las que abastecen precisamente las haciendas de campo) al comercio, pasando por el desarrollo del mercado urbano regional y de las relaciones viales con otros núcleos urbanos y especialmente con la capital virreinal. $Y$ adquiere mayor significado si se toma en cuenta la integración -vertical, tipo holding para retomar una caracterización más actual- realizada por los grandes mineros en sus inversiones $\mathrm{y}$, por lo tanto, en sus actividades económicas. Dueños de unos

s Ibid., 2a. parte: "Du riche mineur au grand propriétaire terrien et á la noblesse"; Bertrand, Grandeur, en prensa. conjuntos económicos a escala regional, estos personajes y la aproximación que se pueda realizar mediante sus comportamientos y actitudes al mundo de la hacienda colonial, de hecho nunca pone en trance la "modernidad" ostentada en las estrategias económicas.

Gracias al control que llegan a ejercer sobre la economía y la sociedad locales, se convierten incluso en los soportes más eficientes de la política de la corona, en un sincretismo y una convergencia de intereses (de estos poderosos y del Estado español) que dista de encontrarse en el mismo momento en la península. Esto sucede no tanto a nivel de los individuos, sino de las grandes familias y clanes familiares - estamos en una sociedad de antiguo régimen, estamental, y en la cual la memoria de la estirpe tiene especial relevancia- y también de determinados estratos de la sociedad colonial. Esta hipótesis, ampliamente comprobada en el caso de los grandes mineros, se encuentra reforzada en sus planteamientos iniciales por el cjemplo paradójico de las órdenes religiosas, grandes propietarios de la tierra y proveedores por excelencia de los capitales anhelados por los nuevos capitanes de empresa. Tal es quizás, aunque en una perspectiva un tanto disímil, la propuesta hecha por John Tutino a la hora de proponer un recuento de la temática agraria novohispana y quien subrayaba en efecto lo siguiente:

la historia agraria, y finalmente roda historia, debe buscar el análisis integrado de la producción, el poder y la cul- 
tura-de la ecología, la desigualdad y las creencias-, factores que siempre se influyen recíprocamente, que siempre están en conflicto.

Sendas cuestionas que de por sí se han estudiado, pero pocas veces se han relacionado y puesto en perspectiva (salvo excepciones como el trabajo de Nancy Farriss sobre Yucatán o de R. Pastor sobre las tierras altas mixtecas de Oaxaca). Hay que añadir en fin, que una evolución similar ya se delinea para los periodos posteriores, especialmente para el siglo $\mathrm{XX}$, si consideramos los balances historiográficos recientes y los "nuevos problemas" planteados al respecto. ${ }^{6}$

IAS TENDENCIAS DEL SIGLO XVIII. HACIENDAS Y MERCADOS: LOS NUEVOS RETOS

A diferencia de lo que sucedió en el siglo XVII y salvo contadas excepciones, el siglo XvIIr es el momento privilegiado en cual se van conformando los espacios económicos. Esta evolución descansa en lo esencial sobre las actividades de tipo comercial, por no decir mercantiles, y por consiguiente, en la formación de mercados regio-

6Tutino, "Historias", 1992, pp. 177 y ss; Chevalier, "Propiedad", 1982, pp. 499 y ss., y cap. v: "Los hombres ricos y pocierosos"; Langue, Mines, 1992, passim; Tortolero, "Hacienda", 1995, pp. 145-166. Del mismo autor una excelente discusión y balance de los debates en torno al tema de los siglos $\mathrm{xIX}$ y $\mathrm{xx}$, "Historia", 1996, pp. 151-178. Véase Tortolero, Tierra, 1997, especialmente la presentación "Historia", y los capítulos de Garavaglia "Atlixco" y Musset, "Tlaloc". nales. Tal es la aseveración defendida desde hace tiempo ya por Carlos Sempat Assadourian ${ }^{7}$ y que continúa conservando relevancia, pues ha sido el punto de partida para los estudios referidos a los circuitos mercantiles. Al mismo tiempo, y como lo subrayó en varias oportunidades Eric van Young, el siglo XVIII fue la era de la paradoja, especialmente en su segunda mitad. En un periodo de esplendor barroco, de gran auge de las economías mercantiles y de prosperidad comercial, pobres y vagabundos recorren el campo e invaden las ciudades, motivando la intervención del Estado español.

Mientras se va reforzando un proceso de regionalización de los distintos espacios productivos, se intensifica a su vez la corriente de los intercambios internos por supuesto, pero también relacionados con la "economía-mundo" estudiada por I. Wallerstein; los primero son altamente despreciados por la historiografía especializada a favor de los segundos, retrospectivamente más prestigiosos. No se trata aquí de valorar el volumen y el valor global de estos intercambios (aunque hay que insistir en el hecho de que se elevan considerablemente en niveles absolutos sin que la productividad progrese de la misma manera, como lo demuestra el estudio de las haciendas novohispanas). Es en realidad el papel incitativo de estos movimientos tanto como sus efectos, perceptibles en primer lugar en la evolución experimentada por las economías locales; más adelante, en el funcionamiento de los

7 Assadourian, Sistema, 1983; Young, "Era", 1992 , pp. 27 y ss. 
centros de producción, ya sea urbanos o bien rurales (haciendas), y sus consecuencias en el modo de vida y la modificación de los estatutos sociales a cualquier nivel de la sociedad indiana, los que nos interesan aquí. A este propósito menciona, aunque con un matiz algo distinto, una reciente recopilación de K. Andrien y L. Johnson, acerca de la "economía política" del imperio español, y del papel de la fiscalidad en la conformación de las estructuras políticas americanas. ${ }^{8}$

Ahora bien, la creciente corriente de los intercambios -legales o no- registrados en el siglo XviI contempla la incorporación de productos de alto valor, que van desde los metales preciosos -en principio controlados por la Corona y sus funcionarios- hasta productos tan específicos como to fueron el añil, la cochinilla o el azúcar. Tanto esta especificidad como la estrecha vinculación que se presentó entre la minería y la gran propiedad, convirtieron indudablemente a muchas haciendas novohispanas en verdaderos complejos económicos y sociales, tales como los empezó a describir para siglos anteriores $\mathbf{F}$. Chevalier, aunque con características específicas para el siglo XVIII.

Tal es el caso de este tipo de complejos productivos integrados en el sentido moderno de la palabra, que significa la asociación en manos de los mismos propietarios, hacendados y grandes mineros a la vez, y a veces banqueros de la plata; en todo caso

\footnotetext{
${ }^{B}$ Andrien y Johnson, Political, 1994; para un panorama de la fiscalidad americana, véase Klein, Finanzas, 1994.
}

accionistas de companías y "aviadores"; son los ejemplos más destacados, las familias Campa Cos y Fagoaga en la región de Zacatecas, Sombrerete, de haciendas de campo -agrícolas o ganaderas- que abastecen, junto a los centros urbanos vecinos, a las minas y a las grandes haciendas de beneficio de minerales de plata - pero también al rastro de la ciudad de México- y de donde salen de la misma manera las mulas que van a formar las recuas que conducen -bajo contrato o "asiento" formalmente establecido- las barras de plata a la Casa de Moneda de la Ciudad de México. Hay que recordar en ese aspecto la importancia lograda por determinadas rutas, tanto la que llegaba de Guadalajara (flujos de ganado estudiados por R. Serrera, quien destaca la tradición exportadora de las haciendas tapatías, así como a los ciclos exportadores especialmente desde Tierra Caliente) como el llamado "camino de la plata", que une a la ciudad de México con las zonas más alejadas del virreinato (Durango, Parral).

Considerado como un factor de producción abundante y barato, el uso de la tierra se combinaba con un uso más intensivo de la fuerza de trabajo disponible en las regiones céntricas. Se da incluso un cambio notable en la producción de las haciendas, que tienden, por lo menos en la región de Guadalajara -tal como lo demostró Ramón Serrera y encontró Brading, como evolución similar en el Bajío- a abandonar la cría de ganado (de ahí la consiguien. te disminución de las exportaciones ganaderas a larga distancia, que pasan de 20000 a 10000 cabezas de ganado a lo largo de ese siglo) para producir 
cereales destinados al mercado interior e incluso urbano, originando de esta manera una reorientación decisiva del comercio ganadero de Nueva Galicia hacia las zonas más pobladas y los mercados urbanos centrales de Nueva España. ${ }^{9}$

Es la ubicación en la corriente de estos intercambios interregionales la que determina el éxito, por no decir la modernidad y la rentabilidad efectiva de las haciendas (haciendas "de dos velocidades": de los empresarios y de los otros dueños), como lo demuestra el estudio de las relaciones que se van estableciendo desde fines de los siglos XVII y reforzando a lo largo del XVIII -a pesar de unas fases de recesión- entre las grandes haciendas, y unas salidas específicas, los mercados urbanos y las minas-haciendas de beneficio. Se considera incluso que se va estableciendo con estas últimas una relación más bien simbiótica que atestigua, por otra parte, la existencia para el siglo XVIII de verdaderos empresarios que son precisamente los grandes hacendados-mineros-ennoblecidos en la mayoría de los casos (Guanajuato, Zacatecas, San Luis Potosí). Habrá que recordar, sin embargo, que en otras regiones, la relación al mercado -local- está en gran medida in.

\footnotetext{
9 Brading, "Hacienda", 1978; Young, "Hacia", 1992, cap. 7; Chevalier, Formación, 1982, p. 351: "La hacienda, nueva unidad económica y social"; sobre las ventajas que el auge demográfico y el desarrollo urbano trajeron para el sector agrícola en general, véase Ouweneel y Torales, Empresarios, 1988; Langue, Mines, 1992, cap. III; "Types", 1992; Serrera, Guadalajara, 1977, cap. III; y del mismo autor, Tráfico, 1992.
}

fluenciada o mediada por el régimen de tenencia de la tierra (asentamientos indígenas, presencia de comunidades de fuerte identidad cultural) o el estatuto específico de sus dueños (la Iglesia), lo que examinaremos a continuación.

\section{Haciendas y mercados locales (minas y centros urbanos)}

El mercado se debe entender no sólo como centro y lugar de distribución de mercancías (de comercialización en el sentido estricto de la palabra) sino también como salida y abastecimiento para la producción agropecuaria local. De ahí la importancia que cobra conforme se va estructurando la economía minera novohispana, la complementaridad que se afirma entre los distintos ramos de la economía colonial: agricultura y minas, en una suerte de integración vertical protagonizada por los grandes mineros hacendados, de hecho los mismos personajes.

Ahora bien, en el norte más que en cualquier otra región de Nueva España, las grandes haciendas desempeñan un papel fundamental en el abastecimiento de los mercados locales. Recordamos que en periodos de crisis, de hambruna, no son los oficiales reales y otros representantes de la corona española quienes toman las medidas más efectivas al respecto. Son los grandes hacendados quienes abastecen a las ciudades con productos procedentes de sus propiedades. Así sucedió en Zacatecas a principios del siglo, cuando el conde de Santa Rosa tomaba sistemáticamente a su cargo la subsistencia 
de los pobres. Desde 1750, el marqués de Jaral de Berrio, minero-hacendado en Mazapil (Zacatecas) y Guadalázar (San Luis Potosí) se responsabiliza del "socorro general de carnes y semillas" de Guanajuato y San Luis Potosí. En 1763 , el conde del Valle de Súchil mantiene a cincuenta familias de pobladores en la "Nueva Bilbao", fundación del aristócrata destinada a asegurar la pacificación de la "frontera" norteña, siguiendo el ejemplo de la "línea de los presidios". Así como en Guanajuato, durante la crisis de los años 1785 1786 , los condes de Regla, de Pérez Gálvez o de Casafiel sacan de sus trojes el maíz necesario para abastecer estas ciudades.

Al mismo tiempo que las haciendas cobran mayor importancia en el abastecimiento de los mercados locales, las grandes y lucrativas haciendas de los jesuitas destinan casi la totalidad de su producción (desde el maíz y el trigo hasta el azúcar, la lana, el pulque y el ganado) a la comercialización. El Colegio de San Pedro y de San Pablo para tomar tan solo estos ejemplos, disponían incluso de una extensa red de intermediarios para comercializar esta producción en los mercados de la ciudad de México, Puebla, Tlaxcala, Texcoco o Pachuca. No es casualidad que, después de la expulsión de los $\mathrm{Pa}$ dres de la Compañía en 1767, quienes compran estas propiedades y sus ganados, son precisamente los grandes empresarios-hacendados ennoblecidos por entonces, o sea los condes de Pérez Gálvez, los herederos del conde de San Mateo Valparaíso o el marqués de Jaral de Berrio. Solo el conde de Regla compró en esa oportunidad (1777) tres de estas haciendas zacatecanas ( $\mathrm{Te}$ tillas, Cieneguilla y Ciénaga Grande). En este contexto se tiende a considerar que los excedentes propiamente dichos, destinados por lo tanto al mercado local, lo producían no tanto las haciendas sino más bien las familias campesinas y los pequeños productores (rancheros). Más al sur, en las relaciones que se establecen con las haciendas interviene otra categoría de actores económicos: los caciques indígenas, quienes son intermediarios entre los productores, las autoridades locales, e incluso con los grandes comerciantes de la ciudad de México. ${ }^{10}$

Cabe preguntarse en qué medida era libremente consentida esta intermediación y si, al predominio natural -habida cuenta de la disponibilidad en términos de espacio- de la gran propiedad en el norte del virreinato se sustituían otros mecanismos encaminados a reforzar el control de las haciendas en la vida económica y social de otras regiones de Nueva España. Sin embargo, los estudios más recientes han insistido en el hecho de que, tanto en Oaxaca como en Yucatán, la producción local siguió en manos de sus proveedores tradicionales, o sea de los indígenas organizados a través de sus comunidades y de sus acostumbrados voceros. Fueron ellos mismos los intermediarios con los mercados urbanos a pesar de la presión constante que quizás ejercieron los dueños de grandes haciendas cercanas a los pueblos de indios, en algunas regiones novohispanas. ¿De qué manera

${ }^{10}$ Riley, Hacendados, 1976; Langue, Mines, 1992, pp. 294 y ss. 
los notables indígenas lograron oponerse a esta presión-que por otra parte resulta ineludible-, o en qué medida actuaron de intermediarios entre los colonizadores españoles, las autoridades hispánicas y sus comunidades de origen, solventando conflictos sobre tierras, reparto de producción o de mano de obra, pero también de orden cultural como los conflictos que se plantearon entre los sacerdotes de los pueblos y las religiones autóctonas?

De este tipo de cuestionamiento depende en realidad nuestro conocimiento del México agrario, o mejor dicho, de los "Méxicos agrarios" y la relativización del poder alcanzado por los dueños de haciendas, tradicionales o modernas, insertadas en redes de intercambios y de mercados. A la par que introduce una dimensión cultural fundamental en la aprehensión de los fenómenos globales, de la misma manera no se pueden analizar las pautas de conductas y las prácticas efectivas de los grandes hacendados norteños, a la vez mineros y comerciantes, empresarios modernos y "racionales", sin tener en cuenta la herencia hispánica que los lleva a fundar este estatuto social con comportamientos de tipo "tradicional", desde las "inversiones sociales" o "suntuarias", hasta el ejercicio del derecho de justicia a lo largo y ancho de sus haciendas, incluyendo el sentido efectivo de los fueros militares o nobiliarios, importancia de los mayorazgos en cuanto institución socia y [...] estrategia patrimonial, búsqueda de títulos nobiliarios y de hábitos de las órdenes militares, constitución de clanes familiares y de clientelas, etc., como se pondrá de relieve más adelante en el caso de Zacatecas. ${ }^{11}$

Cabría plantearse ahora el caso de las haciendas que se dedicaban a la monoproducción. Respecto a la extensión de las propiedades vinculadas a mercados poco evolutivos como lo fueron ciertos productos de alto valor comercial (pulque, azúcar), con una demanda relativamente limitada como fue el caso del pulque, se considera que se adaptaba de cierto modo a las fluctuaciones de ese mercado. Se mantenía una extensión de tierras inculta, a manera de reserva para poder responder precisamente a estas fluctuaciones en pro o en contra del aumento de producción. En cambio, las características de autosuficiencia e incluso de autonomía que se aplican al microcosmos de la hacienda norteña en muy escasos casos se vuelven a encontrar en las haciendas azucareras.

En las haciendas de Morelos, como la de los marqueses del Valle, no se deseaban ni se alcanzaba la autosuficiencia en el siglo XVII. Se vendía el azúcar y se compraba el maíz para la subsistencia de los trabajadores de la hacienda ya que resultaba más conveniente debido a los altos costos de mantenimiento de las instalaciones y al costo de la mano de obra relativamente calificada. Fue en el siglo XVIII en que las haciendas aumentaron sus extensiones de tierras, cuando cambió el panorama. Entre la gran variedad de tierras sólo una parte de las mismas fue utilizada para el cultivo de la caña y existía una vinculación constante de

${ }^{11}$ Tutino, "Historias", 1992; Langue, Mines, 1992, passim. 
intercambios de productos agrícolas y de gente entre una hacienda y otra (lazos familiares, conocimientos, ayuda, etc.). Las haciendas azucareras tendían a producir para un mercado en especial, como fueron las de Morelos para la ciudad de México en el siglo XVII, periodo favorable para este tipo de haciendas como se comprueba en el caso de la hacienda San Carlos Borromeo. La similitud de los intereses sólo en ocasiones desembocaba en conflictos. $^{12}$

\section{Mano de obra y tenencia de la tierra}

A diferencia de lo que sucedió en las minas o haciendas de beneficio de metales, los dueños de haciendas de campo nunca llegaron a ser deudores de sus peones, como fue el caso de las administraciones mineras en que los trabajadores permanecían a la espera de su sueldo condicionado a los ritmos de la economía, a sus ciclos de auge o de depresión que inducen a mecanismos específicos de control de los factores de la producción, que hacía posible la situación de dependencia inversa y por no decir tradicional, ejemplificada a través de la simbólica tienda de raya. El trabajo compulsivo, bajo diversas formas (el repartimiento existía aún en Nueva Galicia hacia los años 1730 y continúa como norma ineludible en el siglo XVIII novohispano, por lo menos en la primera mitad del siglo, en que la gran mayoría de los re-

12 Leal y Huacuja, Economía, 1982, passim; Barrett, Hacienda, 1977, pp. 14-20; Wobeser, Hacienda, 1980, p. 117. partimientos se destinaban en $84 \%$ a la producción de cereales, más particularmente de trigo y sólo $3 \%$ se asignaban a la de maíz. "Gañanes" y "naboríos", amén de condenados y otros reos empleados por la fuerza (a falta de mano de obra) van a poblar tanto las minas como las grandes haciendas de campo. No son excepcionales en este sentido las solicitudes de hacendados o de grandes mineros ante las autoridades locales (corregidores, alcaldes) con el fin de conseguir este tipo de mano de obra. En las siguientes décadas, sin embargo, el trabajo asalariado libre, sumamente desarrollado en el norte del virreinato, cobra mayor vigencia de acuerdo a los ciclos de la economía minera. ${ }^{13}$

Los sueldos en el campo sc pagaban de diversas maneras: en numerario, raciones y en productos de la tierra o manufacturados. Eran en todo caso inferiores a los que se registraban en la minería, aunque hay que recordar que la mano de obra de todas clases podía alcanzar $70 \%$ de los costos de producción de una hacienda de campo (caso de Guadalajara, en la primera mitad del siglo XviII), pero un porcentaje superior a $50 \%$ es la norma para finales del siglo XvIII (por ejemplo, la hacienda triguera de Toluqui1la). Este porcentaje correspondía en 49\% para los peones (segadores, regadores, labradores, pastores, rancheros, mandaderos, etc.); $17 \%$ para los administradores y mayordomos, $5 \%$ para los esclavos, 8\% para los trabajadores especiales o estacionales, y $21 \%$ para

${ }^{13}$ Harris, Mexican, 1975. 
los alimentos (raciones). ${ }^{14}$ Ahora bien, por más que las encomiendas, los repartimientos y otras modalidades de reclutamiento de una mano de obra fundamentalmente indígena, así como la extensión de las grandes haciendas a expensas de las tierras de comunidad hayan desestabilizado la vida campesina y la cultura tradicional, no siempre las comunidades afectadas se vieron destruidas en sus fundamentos económicos y sociales en el sur del virreinato como lo demuestran unos es. tudios recientes. ${ }^{15}$

Se ha subrayado que en la parte central y sur de México, surgieron resistencias y formas de adaptación a las exigencias de mercados en expansión, especialmente en los pueblos que poseían tierras y conservaban por lo tanto una cierta identidad social y una homogeneidad cultural. Éstas se tradujeron, ocasionalmente, en violencia colectiva (diferente de la resistencia "pasiva" manifestada ante los representantes de la Iglesia, los oficiales de la corona, y actores económicos tales como los terratenientes y mercaderes) y desacato a las normas morales impuestas por los españoles. ${ }^{16}$ Las amenazas a esas formas tradicionales de la economía que ocasionaron en esas dos regiones sublevaciones de los pueblos, fueron la conscripción de trabajadores por parte de los funcionarios de la lo-

${ }^{14}$ Frost, Trabajo, 1979; Young, Ciudad, 1989, p. 258.

${ }^{15}$ Young, Ciudad, 1989, p. 251.

${ }^{16}$ Taylor, Embriaguez, 1987 , pp. 19-20; se considera que la población indígena de México aumentó $44 \%$ entre 1750 y 1800 , especialmente en los distritos del centro y de Oaxaca. calidad, del cura o de los hacendados vecinos, pero también la venta condicionada en la tienda del pueblo, de los artículos de primera necesidad (maíz, sal, cal, etc.), o la presencia auspiciada por las autoridades locales en el mercado del pueblo, de vendedores originarios de localidades vecinas.

W. Taylor señala que después del aumento de impuestos y de las exigencias de trabajo, la reivindicación más importante fue la invasión de los linderos y las consiguientes ocupaciones de tierras. Esta última razón provocó 30 de los 142 casos de sublevación estudiados. La tenencia de la tierra en el valle de Oaxaca tenía como característica el hecho de que se había establecido una estrecha relación entre la identidad de un pueblo y un territorio determinado, como lo comprueba el caso del pueblo de Santa Lucía, donde cualquier inspección oficial destinada a medir los linderos, por más que la ordenara un.juez, se enfrentaba a los vecinos que atacaban a los funcionarios públicos, por temor a perder sus tierras como lo subrayó un alcalde mayor, reacción común tanto en la Mixteca Alta como en el propio valle de Oaxaca. En este caso concreto, las nuevas presiones ejercidas en el siglo XVIII sobre las tierras, eran el "resultado al mismo tiempo del aumento de la población y de la expansión de las haciendas productoras de artículos de consumo para los mercados urbanos. ${ }^{17}$

Autores como C. Gibson han insistido en el hecho de que el trabajo asalariado libre estaba relacionado con el

${ }^{17}$ Ibid., pp. 202-203. 
auge de los mercados, por ejemplo en el Valle de México. De hecho, las regiones del centro de México y de Oaxaca fueron en realidad menos afectadas que otras en las modalidades de tenencia de la tierra. Ninguna de ellas tenía capacidad para producir los nuevos artículos de exportación y tampoco eran decisivas allí las inversiones de capitales, a diferencia de lo que sucedía en el mismo momento en las zonas mineras y regiones circundantes. De tal forma que los valles oaxaqueños siguieron el antiguo patrón de los pueblos que poseían ciertas extensiones de tierra y se fueron integrando -desde el punto de vista de la producción y para facilitar la mano de obra a propiedades más grandes- a la corriente de la economía regional y al mercado de la ciudad de Oaxaca. En los lugares donde surgió cierta competencia para la explotación de las tierras y de los recursos naturales (producción de algodón, de sal, cochinilla, pastoreo que no requería de tecnologías tan precisas como la del azúcar), nunca se llegó, sin embargo, a lo que W. Taylor califica de "arrasadoras economías comerciales de Yucatán, Morelos y Chiapas", regiones donde ocurrieron las mayores sublevaciones o incluso insurrecciones campesinas, tanto en el siglo XVIII como en el XIX. La condición "marginal", junto a la consolidación de la identidad étnica tal como la llega a caracterizar para esta región M. Carmagnani, preservó de cierta manera a esas regiones de la intrusión de la modernidad económica y de sus funestas consecuencias sociales inmediatas. ${ }^{18}$

${ }^{18}$ Ibid., p. 220; Carmagnani, Regreso, 1988.
Respecto a la relación entre mano de obra y tenencia de la tierra, resulta imprescindible considerar la participación indígena en los mercados novohispanos, por razones obvias, de acuerdo a interpretaciones realizadas tanto por los avances de la historiografía especializada y sus reflexiones teóricas como por las hipótesis de la historia regional. Una de las interpretaciones más comunes de la historiografía económica consiste en relacionar la decadencia de la producción indígena con el surgimiento de la hacienda que la sustituyó, y en todo caso, intentó limitarla (la producción indígena cayó en manos de intermediarios o la participación al sistema de mercado se hizo de una manera coactiva mediante el repartimiento forzoso). Dicho de otra manera, la expansión territorial de las haciendas tal como se registró en los siglos XVII y XVIII no tuvo otra finalidad que controlar la producción agrícola y en consecuencia el precio de ésta. La competencia que pudo originarse con la existencia de (pequeños) productores (indígenas), cobra cierta validez en la parte norte del virreinato, desde el Bajío aproximadamente (aunque no de manera sistemática, ya que la extensión de las fincas agrícolas no ganaderas adquiere aquí otro sentido, tanto económico como social) no parece en cambio, tan acertada esta interpretación en el caso del centro y del sur de Nueva España. Como se ha estudiado para la región de Chalco o Oaxaca (por los estudios de J. Tutino y W. Taylor respectivamente), la extensión de las haciendas experimentó pocos cambios; en Oaxaca incluso, la propiedad de la tierra les corres- 
pondía a las comunidades indígenas. ${ }^{19}$

De los estudios dedicados al tema de las estructuras agrarias regionales resulta en definitiva que hay que ponderar la importancia que se le confirió al comercio indígena libre (el mismo "repartimiento" se limitaba a la redistribución de unos cuantos productos como fue el caso en el valle de Toluca con el maíz), especialmente cuando se trata del siglo XvIII. En este sentido, se debe considerar, como lo hizo M. Menegus en varios estudios, si las fluctuaciones en la producción indígena "coadyuvaron a los cambios suscitados en la economía novohispana del siglo XVIII", si hubo una contracción de la oferta de parte de los indígenas, particularmente a raíz de la crisis de 1785 . 1786, junto a un auge de la demanda. Hay que recordar en este aspecto que en la región tapatía, en el periodo que va de 1750 a 1770 aproximadamente, los indígenas contribuyeron con $25 \%$ al abastecimiento de maíz de la ciudad de Guadalajara (el porcentaje estuvo más alto todavía en la primera mitad del siglo). Para 1782, había empezado esta cantidad a declinar y no proporcionaban sino $20 \%$ de las cantidades consumidas, y en 1812 no llegaban a $1 \%$ del total, una caída que $\mathrm{E}$. van Young atribuye al aumento de la población indígena que suplía los mercados urbanos locales (se trata por tanto de un consumo interno a las comunidades o pueblos de naturales que

${ }^{19}$ Florescano, Origen, 1976, p. 171; Taylor, Embriaguez, 1987, passim; Tutino, Creole, 1976. impedía la producción importante de excedentes y en consecuencia su comercialización). Al mismo tiempo, en la segunda mitad del siglo, se insistió en la presión sobre las tierras o sus inquilinos. Los contratos de los inquilinos y arrendatarios se hicieron más breves y las rentas más altas. Fue el caso en Tlaltenango, Jerez, Teúl, donde los terratenientes más importantes empezaron a expulsar de manera sistemática a los inquilinos para dedicar sus tierras a la cría de ganado, especialmente de ovejas. ${ }^{20}$

Es significativo el estudio de J.C. Garavaglia y J.C. Grosso, orientado a cuantificar la participación de los distintos sectores sociales en los mercados locales y de las consiguientes pautas de consumo. A través de los resultados proporcionados en gran parte por los registros de alcabalas, resulta en efecto que los grupos indígena y mestizo disputaban la hegemonía del mercado a los hacendados en una ciudad como Tepeaca si tenemos en cuenta el número de individuos, en las transacciones de esta plaza a fines del siglo XVIII. La subdelegación cuenta unos 72000 habitantes a fines del siglo XVIII en que $31 \%$ son españoles o mestizos (castas) que participan en estos intercambios en $55.4 \%$ (españoles $3.7 \%$, mestizos y españoles pobres $40.9 \%$ ). Estos porcentajes son respectivamente de $57.4 \%, 6.3 \%$ y $36 \%$ por lo que se refiere al número de transacciones,

\footnotetext{
${ }^{20}$ Menegus, "Participación", 1995, pp. 136157; Young, Hacienda, 1981, pp. 86-87; Tutino, "Españoles", 1991, pp. 160-185; Young, Ciudad, 1989, p. 244.
} 
aunque en valor, son los hacendados y sus intermediarios los comerciantes los que dominan este mercado $(56.3 \%$ del total). Si consideramos estos estudios dedicados a la participación indígena en la producción comercial, hay por lo tanto que matizar el predo. minio que se le atribuye a la hacienda en la historiografía tradicional y resaltar el fuerte arraigo y la clara vinculación de las comunidades indígenas con la tierra, aunque muchos pueblos perdieron parte de éstas en el transcurso del siglo XVII. Este predominio de las haciendas se funda además en otras realidades (controlan fundamentalmente la comercialización de productos como el maíz, el trigo o el ganado mayor, dejando de lado a una multiplicidad de productos de fuerte consumo que se encuentran en cambio en los tianguis), y en otras regiones: en la mayoría de los casos, contemplan el que atañe a las zonas mineras, no tanto del centro o del sur del virreinato.

Como lo subraya M. Menegus, en el centro y especialmente en un valle de Toluca donde las haciendas y las comunidades tenían una situación privilegiada para vender sus excedentes, por la multiplicidad de los enlaces con las rutas comerciales del virreinato y la proximidad de la ciudad de México y de mercados mineros como Taxco, y Tlalpujahua-Zimapan, se estableció incluso una "relación simbiótica" que no es, sin embargo, sinónimo de equidad por la creciente escasez del recurso básico, la tierra (comunales o privadas), por el auge demográfico y la consiguiente presión sobre los recursos agrícolas. En este sentido las comuni- dades y las haciendas llegaron a depender unas de otras para conseguir mano de obra. En efecto, tanto las comunidades como las haciendas productoras de granos básicos, ganado y pulque se habían convertido en soportes de la "oligarquía urbana". No por casualidad autores como John Tutino se refieren a los pueblos de indios y haciendas de los valles de México y de Toluca como "sectores interrelacionados de la sociedad agraria" especialmente a partir de 1750 . Otro tanto puede decirse de regiones céntricas como la de Tepeaca para la cual se subraya incluso la "capacidad de atracción de población indígena y mestiza" de las haciendas en comparación con las villas circundantes, y el papel de los pueblos de indios en cuanto "reservas" de fuerza de trabajo estacional.

La mano de obra indígena que se empleaba en las grandes propiedades seguía entonces las variaciones estacionales y especialmente la reactivación económica de las haciendas (que se expresa a través de su integración en los circuitos comerciales hacia la ciudad de México o Tierra Caliente, Veracruz por ejemplo). Se integraron jornaleros y peones acasillados (menos de $10 \%$ ), sin contar a los arrendatarios, a diferencia de lo que sucedía en las haciendas norteñas vinculadas en mayor grado a los ciclos de la economía minera. La única excepción la constituye un grupo reducido de trabajadores especializados que se empleaban en el proceso de fermentación de pulque o en el cuidado de animales. El cultivo de cereales predominante en las haciendas del centro sólo requería de un núcleo pequeño de trabajadores 


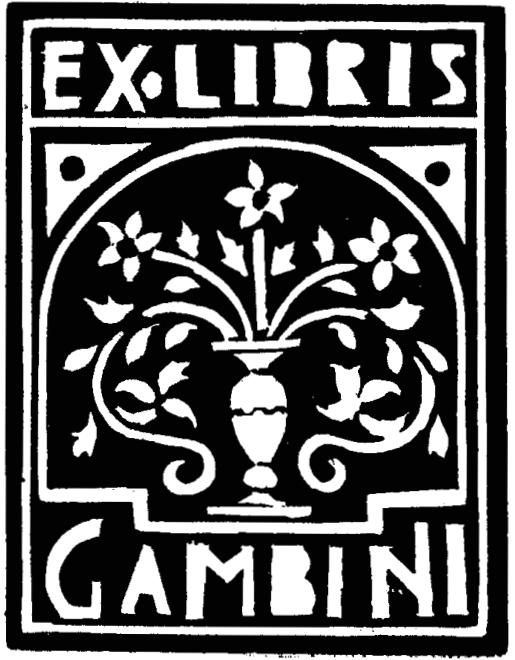

permanentes y de un gran número de trabajadores ocasionales. De ahí las tres categorías que se definieron: sirvientes, administradores y capataces, españoles o mestizos con salarios mensuales (especie de elite de los trabajadores de haciendas que cobraba alrededor de unos cuatro pesos mensuales, además de raciones semanales de maíz que aseguraban sus necesidades básicas especialmente en periodo de carestía); los gañanes indígenas residentes de manera permanente en las haciendas (hasta 25 familias en las zonas algo despobladas), pagados por días (se considera que su sueldo era inferior en $25 \%$ al de los trabajadores permanentes e incluso de los estacionales), y por último, el grupo más nutrido de los indígenas de las comuni- dades (peones o denominados también peones alquilados) que formaban la mano de obra más elástica. ${ }^{21}$

El problema de la mano de obra empleada en las haciendas se ha tratado poco en las monografías o en los estudios de fondo que se han dedicado, desde hace unos cuantos años y con fines diversos, al tema de la hacienda novohispana. Quizás fue una de estas excepciones el avance de A. Bauer, y el de E. van Young. En cuanto al centro del virreinato, se ha insistido ya en la fluidez de las relaciones que se establecieron en el siglo XVIII entre las comunidades indígenas y las haciendas en provecho de unas formas de trabajo no compulsivas (a cambio de unos jornales de diversas índoles por la falta de circulante). El papel compensador de la hacienda en los periodos de crisis (agrícolas, epidemias, hambres) tampoco se debe menospreciar. Muchos de estos trabajadores se convirtieron en peones residentes $y$, por lo tanto, permanentes, endeudados a raíz de estas desventuras. Más al norte, partiendo de Guanajuato y Zacatecas, el esquema más difundido, incluso desde el siglo XVII, fue en defintiva el de una mano de obra asalariada libre (jornaleros, gañanes y arrendatarios) constituida en lo esencial de mestizos (Zacatecas era por ejemplo una de las regiones "más armoniosamente

${ }^{21}$ Garavaglia y Grosso, "Marchands", 1989, pp. 553-580; ibid., Puebla, 1994, pp. 147-249; Garavaglia, "Propiedad", 1990, pp. 33-76; Tutino, "Creole", 1976, passim; "Provincial", 1976, pp. 147 y ss. (reprod. en Miño Grijalva, $\mathrm{Ha}$ ciendas, 1991 y en Young, Ciudad, 1989, p. 123); Menegus, "Participación”, 1995, p. 140. 
mestizas" según W. Jiménez Moreno) y españoles. En este sentido, la producción agrícola estaba orientada hacia la satisfacción de la creciente demanda de las minas. A principios del siglo XIX, en el Bajío, los ranchos que van conformando una suerte de pequeña propiedad y las haciendas, practicaban una agricultura moderna y una concentración de los recursos que lindaba a veces con el despojo de tierras de las comunidades menos arraigadas o de los pequeños productores. ${ }^{22}$

La mayoría de los estudios coinciden en el hecho de que el sistema del peonaje por deudas surgió en realidad por la necesidad de controlar la escasa fuerza de trabajo libre (este sistema es evidente en la minería zacatecana y en las haciendas vinculadas a la actividad minera, pero en un sentido inverso que no siempre se ha señalado: el dueño debía salarios al peón). Ahora bien, en la historiografía agrarista, es más llamativa la imagen de una tienda de raya, símbolo por excelencia de las relaciones laborales y de fuerza que se dan en el ámbito de una hacienda. No estamos afirmando aquí que no existió en el siglo XVII, sólo que no estuvo tan difundido este sistema compulsivo en el norte de Nueva España (especialmente en la región de Zacatecas), aunque sí se afirmó en cambio durante el siglo XIX. La retención de trabajadores del campo por deudas, residentes (acomodados) o

${ }^{22}$ Bauer, "Rural", 1979, pp. 34-63; Young, "Mexican", 1983, pp. 5-61; Brading, Haciendas, 1978. Para un panorama de los salarios rurales en México 1549-1810, véase Young, Crisis, 1992, pp. 115-121.

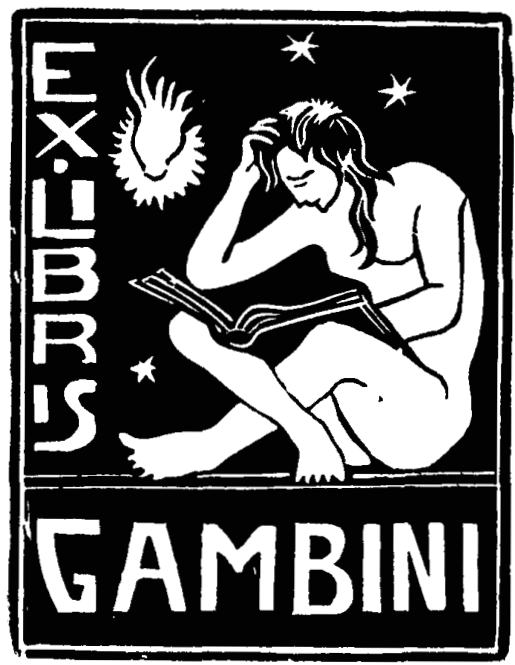

no, se realizaba mediante los adelantos de efectivo o mercancías a crédito. En este sentido, refleja no tanto la debilidad de esta relación sino la fuerza de los interesados. Fue el caso en Guadalajara, hasta bien entrado el siglo XVIII (en determinados momentos, cerca de la mitad de los trabajadores de la región habían contraído deudas, según E. van Young, y esta deuda oscilaba de unos cuantos pesos hasta 50) y hasta se dieron casos de trabajadores que no pudieron cancelar su deuda (y abandonar la hacienda donde estaban trabajando) por negarse el fiscal (pueblo de Nestipac, caso de un indio tributario, 1735) a concederles esta libertad. Con el crecimiento demográfico y la consiguiente ampliación del mercado laboral se fue invirtiendo, esta situa- 
ción en las postrimerías del siglo XVIII y el endeudamiento disminuyó en forma considerable. Si retomamos el ejemplo de Guadalajara después de $\mathbf{1 7 6 0 ,}$ se vuelven excepcionales las deudas globales de 2732 pesos (los trabajadores residentes o "sirvientes" de la hacienda de El Cabezón en 1747 o los 3294 pesos de los trabajadores de Cedros en 1754). En otros términos, la función misma de la deuda que era el mantener un nivel de mano de obra rural suficiente, había sido superada en gran parte por la presión demográfica en el campo. ${ }^{23}$

Los adelantos de sueldo o de bie- * nes, tenían como finalidad atraer a los trabajadores, y se volvieron condición imprescindible para que éstos se comprometieran a laborar. Resulta muy ilustrativo citar aquí el comentario de un testigo en una acción judicial referente a la hacienda de Santa Cruz (Guadalajara) a mediados de siglo: "[...] es tan increíble que la gente operaria trabaje sin avío como coger una estrella con la mano". ${ }^{24}$ Estas prácticas -que incluían la contratación forzada de delincuentes ajusticiados- parecen haber existido en el centro y no solamente en las grandes haciendas norteñas (población flotante) si consideramos los estudios de J. Tutino. Esto quedaría, evidentemente por confirmar con estudios puntuales sobre el enfoque regional.

${ }^{23}$ Young, Ciudad, 1989, pp. 260, 268, 269. Se califica en cambio a los trabajadores estacionales, organizados en "cuadrillas", como "mozos alquilados".

${ }^{24}$ Cit. por Young, ibid., p. 268.
En este sentido, y por las razones expuestas arriba, lo más probable es que no se deba considerar la forma de relaciones sociales y laborales que es el peonaje, especialmente el peonaje por deudas, como un enigma, tal como lo caracteriza E. van Young. En sus distintas variantes, y a pesar de la relativa simplificación del sistema laboral (desaparición del repartimiento), el cuadro de la propiedad del suclo y de las correspondientes formas de trabajo responden de hecho a necesidades precisas, como lo demuestra el ejemplo de las grandes haciendas norteñas, complejos económicos integrados, $y$, de otra manera, la simbiosis entre la pequeña propiedad indígena o comunal de una región como la de Oaxaca y la gran propiedad local.

Está comprobado que, si nos ubicamos en la diacronía, el esquema comúnmente recibido en Nueva lispaña tiene la siguiente estructura: encomienda, repartimiento, trabajo asalariado libre/peonaje, y resulta muy variable según las regiones consideradas, el momento en que se pasa de uno a otro sistema de trabajo (o sea el grado de inclusión de las haciendas en el sistema de mercados regionales, así como el nivel alcanzado en la comercialización de sus productos, disponibilidad de tierra y mano de obra) resultan las regiones norteñas como las más precoces por lo que a trabajo asalariado libre se refiere. ${ }^{25} \mathrm{El}$ problema clave es de hecho la retención de la mano de obra in situ, que no se

${ }^{25}$ Frost, Meyer y Vázquez, Trabajo, 1979; véase en especial el estudio de Tutino, "Life", 1979, pp. 356 y ss.; Gibson, Aztecas, 1967. 
plantea de la misma manera según uno se ubique en las zonas mineras Zacatecas, San Luis Potosí o Guanajuato (donde los dueños llegan con este fin a ser deudores de sus peones) o en Oaxaca, región de población relativamente estable aunque no necesariamente importante (en este caso, hay indudablemente una mayor capacidad de negociación por parte de los trabajadores potenciales), influyendo este último factor en los niveles alcanzados por ese tipo de deudas. El endeudamiento disminuye conforme crece la población total en relación con la disponibilidad de tierra de los campesinos independientes, y por lo tanto, la mano de obra efectivamente disponible, pero también los salarios reales y la capacidad de negociación de los interesados lo que se suele considerar, de forma quizás algo anacrónica. Tal fue la situación que se observó en Guadalajara a finales del siglo XVIII. ${ }^{26}$

En realidad, por más que la accesibilidad de la mano de obra y su mantenimiento en el tiempo, fuera uno de los dos factores necesarios para el desarrollo de la economía de la hacienda junto al desarrollo del mercado urbano, E. van Young lo demostró para Guadalajara; la clave, el fenómeno de concentración de la tierra, que mayor impulso recibió en el siglo xviII a causa del crecimiento de la población novohispana y no necesariamente debido al auge de los recursos agrícolas disponibles, lo cual no siempre se ha examinado de manera totalmente sa-

${ }^{26}$ Young, Hacienda, 1981, cap. XI. tisfactoria. En este sentido, sólo la multiplicación de los estudios regionales aportará los elementos necesarios para profundizar en esta problemática, así como la relativización de ella en función de los distintos contextos regionales. Sin embargo, no está desprovisto de interés tener en cuenta el hecho de que en ningún momento la tierra cambió de sector (campesinado, indígenas, hacia los grandes latifundistas) sino que los cambios que se produjeron en la tenencia legal de la tierra, fueron un producto de los siglos anteriores, como por ejemplo la adquisición de títulos de propiedad (legalizaciones periódicas por medio de las llamadas composiciones de tierras). E. van Young recuerda en ese aspecto el ejemplo de la gran hacienda jesuita de Santa Lucía, al norte de la ciudad de México, propiedad de los jesuitas y estudiada por Herman Konrad. La mayoría de las transacciones relativas a esta finca ocurrieron antes de 1750 e incluso de 1700. Aunque el mismo van Young señala que, de los 85 conflictos y disputas en torno a la misma hacienda de 1576 a 1767, la mayoría (las dos terceras partes) ocurrieron después de 1700.

Otro tanto sucedió en la región tapatía y en Zacatecas. Más todavía: casi todas las propiedades tenían el mismo tamaño en 1800 que en 1700 , lo que no fue incompatible con varios cambios de dueños a lo largo del siglo, o sea con una cierta inestabilidad de la propiedad española de la tierra (un promedio de 4.68 veces en Guadalajara a lo largo de 115 años, o sea, un cuarto y medio de siglo de posesión media, siguiendo el patrón cíclico que 
corresponde en todo caso a la evolución de los precios del maíz, si se corrobora con los estudios de E. Florescano y de C. Gibson. Dicho de otra manera, las modalidades de tenencia de la tierra, la posesión de una hacien$\mathrm{da}$, se relacionaron de manera relativamente estrecha con la evolución de los precios. Lejos de beneficiarse siempre de la escasez o del aumento de precios en años de crisis, el rendimiento medio neto anual del capital agrícola no pasaba de $5 \%$ en una región como Guadalajara, lo que podía provocar la ruina, la venta o incluso terminar en un remate judicial. En los años de 1811-1812, aumentó de manera significativa las ventas de ganado y las rentas de la tierra misma, mientras el año era más bien de cosechas mediocres y precios altos. Este patrón de desarrollo sugiere, por lo tanto, que los hacendados dependían de la renta de la tierra (o de otras inversiones, realizadas en las minas o en el comercio) para compensar las pérdidas de sus operaciones agrícolas. De tal forma que lo que ocurrió en las postrimerías del siglo XVIII, o sea el auge de la agricultura novohispana, no fue, como lo puntualizó E. van Young, sino un

proceso de colonización interna de las propiedades ya establecidas durante los siglos precedentes y no la creación de una agricultura comercial agresiva, hambrienta de tierra a partir de una pieza entera. ${ }^{27}$

27 Young, "Era", 1992, p. 37. Del mismo autor, Ciudad, 1989, pp. 236, 240. Langue, Mines, 1992, cap. vil, pp. 273 y ss.
La Iglesia y la tierra: las baciendas de las órdenes religiosas y el crédito eclesiástico

Las interrelaciones de la Iglesia con la economía quedaban hasta hace poco por investigarse. En términos generales, la atención de los especialistas en temas de historia rural o agraria se habían concentrado hasta ahora (con excepción de la región de Oaxaca), más bien en las zonas del centro y del centro norte de México, de los actuales Estados de Morelos, Puebla, hasta Guanajuato y Jalisco al norte, destacándose Morelos y Guanajuato como estados privilegiados en la historiografía regional. Poco se había investigado acerca de las haciendas norteñas. Salvo la obra de F. Chevalier y la publicación por él mismo del Manual de los administradores de baciendas jesuitas, eran escasos, además los intentos por comprender una realidad compleja, despejando ese campo desconocido y algo desprestigiado por una crítica fundamentada en consideraciones ideológicas y que arranca con el denuncio de Lucas Alamán y se afianza en el discurso liberal del siglo XIX. Desde estos trabajos pioneros, y de unos cuantos análisis de tipo económico centrados en el estudio pormenorizado del diezmo de la Iglesia, varios estudios han ido revelando cuan extensa resultaba ser por ejemplo la empresa agrícola jesuita, y cuan diversos resultaron ser las modalidades de explotación, incluyendo el trabajo compulsivo (repartimiento en la Nueva Galicia a principios del siglo XVIII, mano de obra esclava etc.), y cuan extensa resultaba ser también la esfera de influencia, 
que incluía a los representantes del poder, especialmente del poder local (virreyes, audiencias), y de manera inversa, las discrepancias respecto al derecho de agua y tierra, o al cobro del diezmo. Esto evidentemente, hasta la "revolución en el gobierno" impulsada por los Borbones. Gracias a un material muy rico, las haciendas que estuvieron en manos de los jesuitas fueron estudiadas entonces de una manera más exhaustiva ${ }^{28}$ Hay que recordar en ese aspecto que en la gran hacienda de Santa Lucía, los padres de la Compañía mantenían de manera permanente alojamiento para los virreyes de México, o también la hacienda de la Compañía en Chalco (propiedad del Colegio de San Pedro y San Pablo). Gracias a los sustanciales ingresos que sacaban de estas tierras entre las más productivas y mejor explotadas, los jesuitas financiaron prestigiosos colegios en todo el virreinato tanto en el centro como en el norte del mismo, aunque esta práctica del trabajo agrícola, en propiedades más o menos extensas (labores o haciendas propiamente dichas) la iniciaron también los agustinos y los dominicos, la orden de los betlemitas y de los juaninos (a cargo de hospitales) y algunos conventos de monjas. ${ }^{29}$

\footnotetext{
${ }^{28}$ Riley, Hacendados, 1976; Konrad, Jesuit, 1980; Ewald, Estudios, 1976; o el trabajo de Tovar, "Elementos", 1975; o Pablo Mancera, Nicolás Cushner para el Perú, Germán Colmenares para Nueva Granada, Edda Samudio para los Andes venezolanos, Gustavo Valdés para Chile.

${ }^{29}$ Konrad, Jesuit, 1980 , p. 255; Wobeser, Crédito, 1994, p. 37.
}

El papel de la Iglesia como agente financiero de determinados cultivos o empresas agrícolas ha sido estudiado para otras regiones de América. Para el caso de Venezuela y del cultivo del cacao, disponemos por ejemplo de la síntesis de R. Serrera. La Iglesia desempeñaba este papel mediante préstamos y obras pías, aprovechando por otra parte y con fines diversos la profusión de censos y capellanías fundados. Las fundaciones piadosas a favor de un clérigo de la familia tenían como propósito inmédiato mantener a éste durante sus estudios en el seminario. Asimismo fueron de gran utilidad a la hora de fundar misas, o de conseguir crédito, y también -lo que no contradice de ninguna manera lo anteriorcuando se buscaba realizar inversiones suntuarias y obras de prestigio, relacionadas con el estatuto social del fundador y de un grupo familiar parte integrante de las elites coloniales. Estas circunstancias están despertando hoy en día un creciente interés entre los especialistas de la economía y de la sociedad colonial. Verdadera institución bancaria cuyos préstamos tienen una contrapartida en lo espiritual, a través de las fundaciones de misas, de las fiestas religiosas, o del sostenimiento de los párrocos, la Iglesia novohispana sin embargo poco se ha estudiado por lo que toca a la naturaleza de las deudas contraídas a su favor como lo indica Águeda Jiménez, quien subraya por otra parte la necesidad de las haciendas de recurrir al crédito a intervalos regulares, tanto en periodos de crisis como durante los periodos de prosperidad.

En otros términos, el punto álgido de estas interpretaciones y compren- 
sión de la hacienda en cuanto actor económico y social radica en la diferencia existente entre préstamos y grávamenes, o sea el significado de las deudas que pesaban sobre las propiedades, si se había recibido dinero en efectivo o si se trataba exclusivamente del reconocimiento de una carga anual. De hecho, resulta sumamente aleatorio, y en primer lugar por una razón de terminología indecisa en no pocos casos. En Nueva Galicia, el "censo" tiende así a desaparecer del vocabulario en provecho de la "capellanía" y de las "escrituras de obligación a depósito irregular". Hay que distinguir, por otra parte, entre las fundaciones propiamente dichas, los llamados "principales" y sus consiguientes réditos ( $5 \%$ anual) que se van acumulando conforme se van sucediendo unos a otros los dueños de las haciendas, y el capital "líquido" que se conseguía como préstamo del llamado Juzgado de Capellanías, testamentos y obras pías, organismo encargado del manejo de estos fondos. Se considera que este tipo de escrituras se va difundiendo en el siglo XVIII. En el sur de Zacatecas, los porcentajes más altos se registran entre 1740 y 1800 , aunque en la mitad de los casos, no se trata de préstamos propiamente dichos sino del reconocimiento de una hipoteca anterior, pudiéndose redimir estos préstamos a 50 o 100 años, incluso después de haberse gravado la propiedad. Los montos de estas fundaciones eran muy variables, fluctuaban por lo general entre 2000 y 3000 pesos, lo que producía una renta anual de 100/ 150 pesos. No obstante, se dieron casos de fundaciones por un monto más elevado (hasta 6000 pesos), cuando los representantes de la elite novohispana fundaban capellanías para sus hijos o allegados. El caso de José de la Borda, quien fundó una capellanía por 60000 pesos (para su hijo) o del segundo conde de Jala quien se hizo sacerdote al enviudar y vivió de una capellanía cuyo capital alcanzaba los 200000 pesos, son sin embargo excepcionales por la magnitud de las inversiones así realizadas. ${ }^{30}$

Varias órdenes religiosas estuvieron implicadas a través de sus conventos y seminarios en este proceso a la vez de ampliación de los recursos eclesiásticos y de control de la economía novohispana por medio de las tierras, aunque esta situación sufrió consiclerables variantes según las regiones. En Guadalajara o Zacatecas, y, de manera general en el norte del virreinato, la Iglesia actuó más como agente financiero que como propietario directo de la tierra, a diferencia por ejemplo de las casas religiosas de Oaxaca a finales del siglo XviII. Catedrales, parroquias y cofradias también participaron en este doble proceso conjunto de inversiones realizadas mediante el otorgamiento de préstamos y de ocupaciones de tierras. El poder alcanzado por los clérigos atestigua el pleito que se

${ }^{30}$ Para un análisis de las distintas categorias de censos, véase Wobeser, Hacienda, 1980 , pp. 87-92 y Crédito, 1994, cap. II: "La inversión de capital eclesiástico"; Medina, Iglesia, 1983, passim; Hamnett, "Appropriation", 1969, pp. 86-87; Lindley, Haciendas, 1987, p. 57 y ss; Lavrín, "Capital", 1985, pp. 6 y ss; Jiménez, "Crédito", 1993, pp. 97-111; Greenow, "Spatial", 1979, pp. 227-280; Jiménez, "Crédito", 1993, p. 104. 
inició en 1754 en el obispado de Michoacán, a raíz de la solicitud que les hicieron las autoridades eclesiásticas y en última instancia, civiles, a los agustinos para que éstos presentaran los títulos legales que los amparaban en la posesión de la doctrina de Yuriria. El padre provincial trasladó su residencia a la misma hacienda de San Nicolás, ubicada en Yuriria, para participar de manera más efectiva en el proceso judicial (reclamo) iniciado por la orden a consecuencia de la entrega de la iglesia, del convento del lugar, así como de unas alhajas y de unos sitios de ganado mayor. Una Real Cédula de Fernando VI (1753), amparó a los religiosos en la defensa de las propieda. des. Sólo en 1761, a través de un hábil manejo de la legislación indiana, iba a lograr el procurador de la orden que el mencionado convento se reintegrase a la Provincia con todas sus rentas, quedando solamente a la parroquia los ornamentos de uso cotidiano. ${ }^{31}$

Para la región caxcana, en el sur de Zacatecas y Jalisco (Juchipila, Tlaltenango, Teocaltiche), se ha establecido a partir del estudio de los registros de hipotecas de bienes raíces, que "el

${ }^{31}$ Figueroa, "Agustinos", 1992, vol. I, pp. 203-210; Navarrete, Historia, 1978, t. I, pp. 517-18. Desde su llegada a Michoacán, los frailes demostraron no poco interés por la tierra y llegaron a acaparar considerables extensiones en pueblos de naturales. Las disposiciones reales encaminadas a restringir el acaparamiento de tierras tanto rústicas como urbanas no siempre fueron acatadas. En el siglo xvi y todavía en la primera mitad del siglo xvili, fueron las composiciones de tierras el medio por el cual la iglesia logró legalizar estas ocupaciones. El conflicto de Yuriria se enmarca dentro de este proceso de reclaniaciones recíprocas. capital que fluyó de la Iglesia hacia el mercado del crédito" fue de 546896 pesos de 1670 a 1821; en esta región representativa de este proceso a escala del virreinato, equivalía al $74.1 \%$ del total de los préstamos registrados. De tal forma que el endeudamiento tuvo como consecuencia directa un monopolio de la Iglesia sobre la propiedad de la tierra (haciendas o ranchos), pero también de las fincas urbanas ya que un porcentaje alto de las mismas estaba en manos de los conventos o de otra institución eclesiástica. Hay que señalar en efecto que en semejante actividad crediticia participaron, aunque en forma más modesta, instituciones estrictamente educativas y de beneficiencia: colegios, terceras órdenes, hospicios y hospitales, recogimientos y hermandades. El retraso en el pago de los réditos afectaba de hecho los ingresos de las instituciones eclesiásticas y el compromiso así contraído ocasionaba la venta o mejor dicho el remate de la propiedad hipotecada, por concurso de acreedores. Tal es el sentido del concurso de acreedores que se hizo en contra de los bienes del marqués de Torrecampa, don Joseph de Cossío y Campa, quien había recurrido al crédito en varias oportunidades para comprar, a mediados del siglo XVIII, unas haciendas ganaderas en Durango, haciendas que, sin embargo, no llegaron a prosperar. Habiendo pasado a la Inquisición los bienes de uno de los prestamistas, la Inquisición se hizo acreedora en 1753 y se arrendaron o remataron varias haciendas en los años siguientes; asimismo se concedieron varias prórrogas. De tal forma que para 1822 , des- 
pués de la desaparición del principal acreedor, la Inquisición continuaba el concurso de acreedores y hasta tenía un adeudo de 108668 pesos a su favor. En una fórmula lapidaria, D. Brading señaló que "la hacienda mexicana era un barril sin fondo que consumía sin cesar el capital excedente acumulado por el comercio exterior" pero añadía lo siguiente: "Las fortunas amasadas en la minería o en el comercio se invertían en la tierra, para desde allí ser lentamente dilapidadas o transferidas poco a poco a las arcas de la Iglesia", induciendo un lento proceso de desplazamiento de la clase hacendada, que no iba a finalizar sino hasta la Revolución de 1910. ${ }^{32}$

Recordemos tan sólo unas cifras expresivas de esta tendencia. Solamente en el obispado de Michoacán, el diezmo produjo, en el año 1787 , unos 330000 pesos, las limosnas y cuotas clericales ascendieron a una cantidad comparable, y los réditos de capellanías a 147000 pesos. La prueba más contundente del control logrado por la Iglesia en la economía novohispana se dio en 1804, cuando se publicó la Real Cédula llamada de Consolidación de Vales Reales. No insistiremos aquí en el sentido de esta medida encaminada a consolidar las finanzas del Estado metropolitano ya que son numerosos los estudios detallados que se han dedicado a este tema. Sólo consideraremos las consecuencias que tuvo este decreto para el gobierno de una Igle-

\footnotetext{
${ }^{32}$ Rubial, Convento, 1989, passim; Bauer, "Iglesia", 1995, pp. 19 y ss; Brading, Mineros, 1975, p. 297; Wobeser, Crédito, 1994, pp. 110 -
} 113. sia novohispana convertida en aquel entonces en el mayor propietario rural del virreinato, si nos referimos a las anotaciones hechas en la época por el barón de Humboldt. Por esta disposición, se mandaba confiscar en efecto las propiedades en forma de censos y bienes raíces de las obras pías y de las capellanías, de las cofradías y de las órdenes terceras, de los santuarios, hospitales, casas de misericordia y otras instituciones eclesiásticas a favor de la Real Caja de Consolidación de Madrid. Para el año de 1809, las cantidades recaudadas por este concepto ascendían a 10.3 millones de pesos, y eran el arzobispado de México y el obispado de Puebla los mayores contribuyentes con $70 \%$ del total (rebasando el millón de pesos anuales). En tercer lugar venía el obispado de Michoacán (en 1807 llegó a 430000 pesos), el más reacio en acatar esta medida si recordamos las reiteradas representaciones que en su contra se elevaron desde su sede a la Corona española. ${ }^{33}$

Esta medida afectó por lo esencial a los dueños de haciendas rurales (beneficiarios en tan sólo $16.2 \%$, según G. von Wobeser de los préstamos concedidos por las instituciones eclesiásticas), contra $43.8 \%$ a favor de los comerciantes, repartiéndose el resto a favor de diferentes sectores sociales (mujeres, clérigos o funcionarios públicos), medianos y pequeños labradores pero también a comerciantes, grandes y pequeños, y al mayor dueño de

\footnotetext{
${ }^{33}$ Bauer, "Iglesia", 1995, pp. 19 y ss; Silva, "Consolidación", 1992, vol, 2, pp. 65-80; Marichal, "Iglesia", 1989, pp. 103-129; Wobeser, "Mecanism", 1989, pp. 1-23.
} 
la tierra: la Iglesia. Por ser el crédito eclesiástico era una fuente importante de financiamiento para comprar tierras o propiedades rurales y mejorar la infraestructura de las propiedades agrícolas, los dueños de la tierra se vieron en la obligación de vender sus propiedades, o de renunciar a sus inversiones y al giro de sus negocios por la falta de pago de los intereses/réditos. Aparentemente, fueron mayoritariamente criollos los hacendados que protestaron en contra de esta medida. De hecho, se puede considerar que se trataba de una economía agrícola "dependiente" como lo puso de relieve Arístides Medina para la región poblana. Unos cuantos ejemplos: un hacendado como Francisco Javier de Villaseñor y Cervantes había obtenido de esta manera 4000 pesos del convento de San Bernardo para el cultivo y el avío de una hacienda de labor y de ganado mayor. Francisco de Olmedo y Luján había utilizado los 4000 pesos prestados por el convento de San José de Gracia para reedificar unas trojes en su hacienda de Xochimilco.

En el siglo XVIII, los préstamos a favor de hacendados resultaron convenientes para las instituciones eclesiásticas sólo cuando se trataba de préstamos por periodos cortos y mediante depósito irregular, garantizados mediante una hipoteca sobre bienes raíces y/o mediante fiadores. El hecho de que la mayoría de las haciendas estuviesen endeudadas (en más de 50\% de su valor, y hasta $90 \%$ en los casos más extremos, por unos censos o hipotecas que se remontaban a veces en el siglo XVI, iba en contra de la garantía material y de la estabilidad patrimonial que conllevaba tradicionalmente la propiedad de la tierra. En la Intendencia de Puebla, la ley de Consolidación desató una crisis financiera, afectando en adelante todo tipo de préstamo. Matizando un poco esta perspectiva, se llega en realidad a la conclusión de que este fenómeno atañe en realidad a las grandes propiedades. Fue también uno de los hallazgos más significativos de la investigación de W. Taylor para Oaxaca, fundándose en una "racionalidad propia" del sistema crediticio colonial. Quizás esta inestabilidad de la gran propiedad, esta tendencia al endeudamiento (hasta el 80 o el $90 \%$ en el valle de Oaxaca) y por lo tanto a la quiebra en años de condiciones desfavorables, a lo ancho del virreinato novohispano, sugiera que se había instalado una competencia que sólo el estudio sistemático de los diezmos permitiría comprobar plenamente. No eran menos significativas las deudas contraídas en Cholula (hasta $70 \%$ ), o en Tlaxcala donde varias haciendas estaban gravadas hasta por dos tercios de su valor. En Michoacán, si bien la Real Cédula de 1804 afectó esta forma específica de crédito, parece que no llegó a desorganizar el sistema crediticio en su conjunto, según afirmaban las mútiples representaciones. ${ }^{34}$

${ }^{34}$ Cervantes, "Declive", 1995, p. 136; Garavaglia y Grosso, "Mexican", 1990, p. 266; Sánchez, "Capellanía", 1995, pp. 119-129; Silva, "Consolidación", 1992, pp. 65 y ss. 


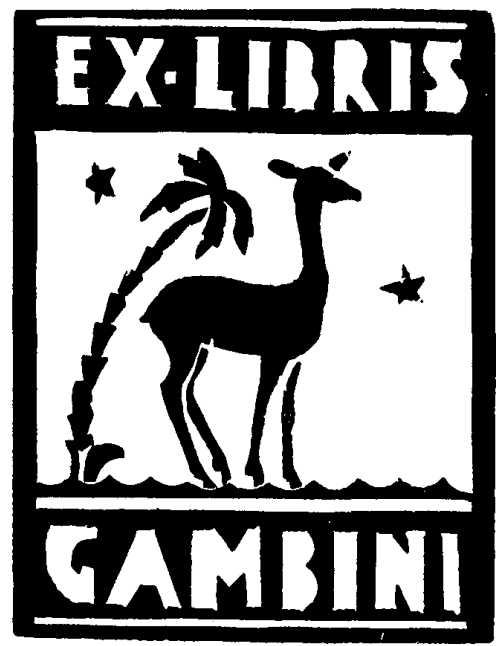

TRAYECTORIAS DIFERENCLALES: LAS ESTRUCTURAS AGRARIAS REGIONAIES

Si bien se reconoce la importancia de los estudios cuantitativos realizados en este campo de la historia social y económica (E. van Young, C. Morin, R. Pastor), se ha comprobado ampliamente que la tipificación regional esbozada por F. Chevalier (los dos Méxicos), la zona norteña, de cierto modo la zona intermedia del Bajío (por resultar más ligada al inmenso mercado que constituye la ciudad de México y en primer lugar por una razón de proximidad a las corrientes de los intercámbios) o la región azucarera de Morelos, Oaxaca y Yucatán, sigue vigente. Se ha comprobado gracias a la multiplicación de los estudios dedicados a la historia agraria del México colonial, que, junto al "modelo inicial" que fue el del norte, coexistían modalidades muy diversas en cuanto a tenencia de la tierra y otros tantos patrones de desarrollo. Más todavía: se comprobó que la estructura agraria de fines del periodo colonial tenía una compleja y contrastada distribución en cuanto a tipos de unidades de producción en comparación con lo que sucedía con las grandes haciendas y pueblos de indios. En Oaxaca la propiedad indígena, de tamaño modesto registró un aumento en el siglo XVIII (no tanto en lo que a extensión se refiere sino al número de las propiedades) y las pequeñas propiedades no indígenas desempeñaron un papel de intermediarios entre las comunidades indígenas y las haciendas, contribuyendo a articular y flexibilizar las relaciones entre ambos sistemas; y en el centro-oeste y centro-norte, o sea, en el Bajío, en Michoacán y en menor grado en Nueva Galicia las pequeñas propiedades o ranchos lograron sobrevivir al lado de las grandes haciendas. Estas evoluciones diferenciales y coyunturales son las que permiten precisamente relativizar las caracterizaciones globalizantes que, con suertes muy desiguales, varios estudios intentaron estamparle al siglo XviII: nueva edad de oro, nuevo siglo de la depresión o "claroscuro". ${ }^{35}$

3s Brading, Haciendas, 1978; Coasthworth, "Historiografia", 1988, pp. 277-291. Existe un panorama bastante completo de las relaciones entre la estructura agraria del México colonial y la gran propiedad en Menegus, Problemas, 1995. Para el periodo colonial véase a Hamnett, "Obstáculos", 1995; Florescano, "Problema", 1995; Flores, "Consolidación", 1969, Pp. 334-378; véase también Morin, Micboacán, 1979; Young, Crisis, 1992, cap. 5, pp. 247 y ss. 
Las haciendas norteñas integradas: el reinado de los grandes mineros-terratenientes $y$ comerciantes

En el transcurso del siglo XVIII, el norte del virreinato (desde el Bajío, Guadalajara y hasta Michoacán) se convirtió en una de las regiones económicamente más dinámicas, por el efecto de arrastre de las minerías locales (Guanajuato, Zacatecas y, a fines del siglo, Real de Catorce). De ahí la aparición de asentamientos poblacionales, los reales de minas, elementos fundamentales de la colonización tanto militar y espiritual o económica desde los inicios del siglo XVII y el desarrollo de los llamados "caminos de la plata". En esta variante norteña, predominante a partir del Bajío, las grandes propiedades controlan la tierra y la población local gracias a varias combinaciones en cuanto a tenencia de la tierra (incluyendo el arrendamiento o el acaparamiento de tierras); en este sentido las propiedades más notables formaron parte de destacados conjuntos económicos (minas-haciendas). Una excepción, aunque muy relativa la constituye el extremo norte (Sinaloa-Sonora) en su condición de zona fronteriza (inestabilidad de asentamientos rurales, empresa misional y oposición de los colonos españoles para la explotación de la mano de obra, rendimientos insuficientes), las haciendas se presentan por lo tanto como unos núcleos de población antes que unidades económicas integradas. Aunque puede suceder que estén ligadas a unas minas vecinas como fue el caso en las cercanías del Rosario o en el real de la Cieneguilla, o

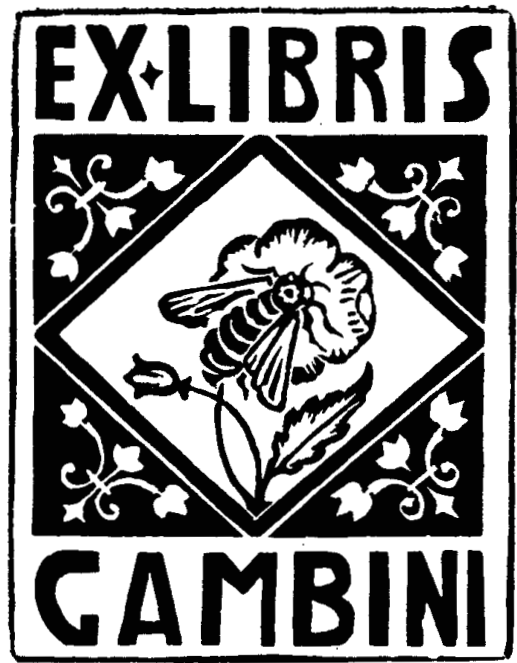

yendo hacia la región minera de Parral. En este último ejemplo habría que senalar sin embargo, que no pocos complejos mineros (minas y haciendas de beneficio) se abastecían en las lejanas haciendas de campo zacatecanas, propiedad de uno de los precursores más destacados en materia de integración y concentración de las actividades económicas, Juan Alonso de la Campa, sobrino del conde de San Mateo Valparaíso, y miembro de la influyente dinastía Campa Cos, quienes eran mineros, hacendados y comerciantes, presentes hasta en la ciudad de México. ${ }^{36}$

${ }^{36}$ Para un panorama económico y social de esta región y acerca de la expansión del espacio agrícola a raíz de la decadencia del sistema 
Minero instalado en las inmediaciones de Zacatecas (en el centro minero de Vetagrande), Alonso de la Campa Cos combinaba en su persona todos los rasgos del empresario moderno. No obstante su poder descansaba en una red tradicional de relaciones familiares -incluyendo el parentesco espiritual- y de amistad. Aprovechándose de las dificultades experimentadas por otras grandes familias locales (los condes de Santa Rosa o de Santiago de la Laguna), había comprado unas cuantas haciendas de campo -Malpaso y Palomas- cuya característica más sobresaliente era el haber pasado, a lo largo del siglo, de un gran minero-hacendado a otro, aunque permaneciendo siempre en el marco de la "gran familia" constituida por la elite local. La "división del trabajo" era el imperativo mayor de la familia así como el control de las actividades económicas en todos los niveles de la producción y de las decisiones o acuerdos que se pudiesen adoptar en el seno del cabildo zacatecano: las haciendas del conde de San Mateo abastecían las minas de su sobrino y de la propia ciudad de Zacatecas. Juan Alonso Díaz de la Campa -quintó 17.3\% de la plata de Zacatecas entre 1725 y 1750 , o sea un porcentaje superior al de José de la Borda para el periodo 1775-1800- controlaba junto a su tío el conde de San Mateo el "abasto de carnes y candelas" tanto en Zacatecas como en la villa vecina de Vetàgrande, y ejercía un monopolio que el virrey Juan Francisco de Güe-

misional, véase Escandón, "Economía", 1993, pp. 361 y ss; Hadley, Minería, 1975. mes y Horcasitas no vaciló en declarar "incompatible" con la responsabilidad de alcalde mayor del interesado. Como lo indicaban los mineros del lugar, las minas locales dependían "totalmente" de las haciendas del conde y de su parentela. La familia estaba presente en varios puntos neurálgicos de Nueva España: en Sombrerete, centro minero relativamente próximo a Zacatecas y donde reinaba el general $\mathrm{mi}$ nero-hacendado Antonio de la Campa Cos (hermano del conde), pero también en la ciudad de México o en Veracruz. En 1724, Fernando de la Campa Cos, futuro conde de San Mateo Valparaíso, figura entre los proveedores más importantes de carne (ovejas) en el centro minero de Santa Eulalia (Chihuahua) y también entre los más competitivos, al ofrecer precios inferiores (a pesar de la distancia registrada entre sus haciendas ganaderas convertidas -según la fórmula de P. Hadley en "entidades económicas de pleno derecho"-, y este mercado) a los de sus vecinos hacendados de Parral o de San Felipe en el mismo momento. ${ }^{37}$

Terminaremos esta evocación del centro minero zacatecano y del grado de "integración" alcanzado por los modernos complejos económicos que forman las minas y haciendas, recordando tan sólo otro ejemplo, el de José de la Borda, más conocido gracias al estudio de D. A. Brading, quien le atribuye la "resurrección" de Zacatecas en cuanto centro minero y económico en general. Si José de la Borda es efectivamente un ejemplo relevante de mentalidad empresarial, de estrategias

${ }^{37}$ Langue, Mines, 1992, pp. 127-128. 
económicas ciudadosamente planeadas, hay que tener en cuenta que la recuperación de Zacatecas se inscribe dentro de un proceso local iniciado en la primera mitad del siglo, confortado por las reformas de la Corona en ese campo de la economía (exenciones fiscales). Cuando llegó a Zacatecas, José de la Borda no era un desconocido (1767). El autor de los Comentarios a las ordenanzas de minería, celebró reiteradamente su capacidad organizativa y sus logros en materia de minas. Pero como la mayoría de los mineros, Borda había sufrido reveses de fortuna. Acababa de perder el caudal realizado en las minas de Taxco y Tlalpujahua, cercanas a la ciudad de México, en inversiones arriesgadas, así como en otras minas que no resultaron rentables, y en inversiones sociales e incluso suntuarias, por ejemplo la iglesia de Santa Prisca en Taxco, joya de la arquitectura colonial mexicana. Sus deudas - a favor de aviadores o de banqueros de plata como Manuel de Aldacoascendían en ese momento a 400000 pesos.

El 12 de marzo de 1768 , se publica la primera Real Cédula que le otorga a un minero de Nueva España una exención fiscal. La referida exención, cuyo beneficiario fue José de la Borda, cubría el periodo de recuperación propiamente dicho (exención total) y un periodo adicional durante el cual se pagaría $50 \%$ del diezmo (durante 20 años) y se facilitaba el azogue a 30 pesos el quintal. Gracias a los préstamos de los aviadores Aldaco y Olamendi y de la corona por un valor de 50000 pesos, se rehabilita la mina de Quebradilla, punto de partida para la constitución de la segunda gran compañía minera zacatecana; en ocho años, sólo esta mina produjo utilidades por 750000 pesos. En el mismo periodo, Borda construyó la hacienda de beneficio de la Sauceda, la más grande del norte, elemento clave de la integración proyectada por el minero, continuando así la pauta iniciada por Juan Alonso de la Campa. Asimismo adquiere la hacienda de campo de Malpaso a la que nos referimos anteriormente (en 102000 pesos). Esta hacienda iba a abastecer de manera duradera el complejo productivo formado por minas y haciendas de beneficio, tanto en animales de tiro (1 400) mulas para los malacates) como en maíz para los trabajadores. Cuando murió en 1779, José de la Borda no sólo había cancelado sus deudas (en cinco o seis años) y emprendido el costoso desagüe de la legendaria mina de la Quebradilla -con las halagüeñas cirunstancias que se conocen- sino que dejaba una fortuna estimada en 1000000 de pesos, incluidos $300(000$ pesos invertidos en fincas urbanas en la ciudad de México. ${ }^{38}$

\section{El centro-sur: una evolución diferenciada}

Yendo hacia el centro y el sur, se nota la existencia de haciendas de menor extensión, colindantes con comunidades indígenas más estables (a diferencia de la población flotante que pre-

${ }^{38}$ Ibid., pp. 133 y ss; Gamboa, Comentarios, 1761; Brading, "Mexican", 1970, p. 670. 
domina en el norte, y que sigue predominando por los ciclos de la economía minera de estas zonas), en las cuales tienden a contratar mano de obra temporal. También se registran casos de propiedades en donde se emplea mano de obra esclava. Tal es el caso de las haciendas yucatecas que estuvieron en manos de encomenderos-estancieros a lo largo del siglo xvI y más adelante pertenecieron a comerciantes-estancieros: sus dueños se dedicaban con no poca frecuencia a la compraventa de negros, aprovechando su presencia en los cabildos locales (Mérida, Valladolid, y sobre todo, Campeche) o lazos de parentesco. En las haciendas norteñas en cambio, los trabajadores residentes -libres, asalariados o "acasillados", por deudas- constituyen, como tuvimos la oportunidad de examinarlo, la mayoría de los peones empleados en las haciendas.

En Oaxaca, fueron los caciques y las comunidades indígenas quienes se mantuvieron a cargo de la producción, y predominó también la organización comunitaria en zonas templadas e intermedias como la del valle de Toluca. De manera general, en estas regiones con menor presencia de población hispánica, algo alejadas de las corrientes de intercambio, fueron las elites indígenas quienes ejercieron el poder local, controlando el uso y hasta la propiedad de la tierra y comercializando sus productos hasta bien entrado el siglo XIX. Más todavía, si bien la producción española o mestiza llegó a desplazar gradualmente a la producción indígena, la combinación de "economías campesinas perdurables" y la presencia de elites indígenas dio como resultado la persistencia de "culturas regionales" mayas o mixtecas cuyo modo de vida se alejaba en muchos aspectos del esquema hispánico predominante. ${ }^{39}$

Las variaciones afectan tanto a las modalidades de tenencia de la tierra, en especial a la organización comunitaria y los patrones de propiedad, como a las relaciones con mercados urbanos o sistemas de trabajo. Este fenómeno se puede vislumbrar delineando la curva de los ingresos registrados por cajas reales; las regiones más dinámicas en este aspecto son las zonas mineras de Guanajuato, y Zacatecas, con un efecto de arrastre en los demás ramos de las economías regionales. Asimismo, las hipotecas se relacionan de manera directa con los ciclos de crisis agrícolas. ${ }^{40}$

39 Trabulse, Fluctuaciones, 1979. González, Cabildos, 1994; Farriss, Maya, 1984; Taylor, Landlords, 1972; Loera, Economía, 1981; pastor, Campesinos, 1987. Hay que recordar sin embargo que las cifras no siempre son indicadores fiables de la realidad cotidiana, J. Coastworth estimaba en las dos terceras partes o más de la producción novohispana, las cantidades que por razones diversas, se le escapalsan al recaudador de impuestos, lo que, dicho sea de paso, tiende a invalidar cualquier intento de interpretación fundada exclusivamente en el estudio de la fiscalidad. Además, en Oaxaca, el porcentaje alcanzado por la producción indígena representa solamente la producción agrícola de tipo europeo. La contribución indígena al diezmo no indica gran cosa con respecto a la producción de maíz, que era el cultivo más importante para la población indígena, tampoco trae mayores informaciones respecto a los derivados de la grana y del maguey cultivados tradicionalmente por estas comunidades.

${ }^{40}$ Véase Klein, "Economías", 1991, pp. 154 y ss. 
Tal era el caso en los valles centrales de Oaxaca donde el fenómeno se agudizó entre 1699 y 1760, donde no está por demás recordar la crisis de mediados del siglo XVIII, provocada en el conjunto de Nueva España por causas externas: epidemias de matlazáhuatl o hambrunas originadas por el estancamiento de la producción; la falta de mano de obra, producto de lo anterior, impidió que los terratenientes oaxaqueños constituyesen un grupo cerrado, en consecuencia de la pérdida de sus propiedades, ya que no podían pagar los réditos de sus deudas, como lo subrayó W. Taylor. En las zonas mineras, los ciclos de la producción de plata influyeron de manera directa en el porvenir de las propiedades agrícolas (por más que el destino de éstas tenga también repercusiones en la buena marcha de las minas y haciendas de beneficio de metales). Siempre que disminuye la producción, decae el comercio, y se va la mano de obra flotante que se suele emplear en las minas (Zacatecas, Guanajuato). De ahí sus consecuencias en las haciendas, ya sean propiedad de minerosempresarios o no. En este caso, sólo la diversificación de las inversiones impide que las haciendas vengan a menos, y con ellas, el prestigio social de los interesados. Ahora bien, en los periodos de crisis como el de Zacatecas 1730 a 1760 , los verdaderos empresarios aprovechan el endeudamiento de sus competidores para comprar sus propiedades, de tal forma que las haciendas rurales (hipotecadas hasta 60\% de su valor) suelen tener alrededor de cuatro o cinco dueños a lo largo del siglo XVIII.
La "retención" de tierras por parte de las comunidades tuvo como consecuencia el desarrollo de una elite de comerciantes, que se apoyaba, hasta la creación de las Intendencias en 1786, en la eficiente red de los alcaldes mayores. Algunos se hicieron productores de azúcar en tierras rentadas por las comunidades (Mixteca), otros se dedicaron al comercio de los textiles o colorantes. La creciente penetración mercantil en la economía indígena se encontró en gran medida facilitada por el repartimiento de mercancías. De tal forma que en el caso oaxaqueño, las comunidades terminaron envueltas en la red de los intercambios a la par que se iba conformando una estructura comercial privada que se constituyó arriba de la red local de mercados indígenas. Un estudio reciente destaca el carácter voluntario de ese sistema de repartimiento de mercancías -presentado como un sistema de consumo a crédito- y en la consiguiente participación de los campesinos en los mercados. ${ }^{41}$

Otra característica de estas regiones la constituye el predominio y el desarrollo de propiedades de tipo particular. Las haciendas azucareras o ingenios de azúcar eran unidades complejas de producción, que requerían extensas propiedades en valles planos e irrigados para el cultivo de la caña de azúcar, y que además disponían de capitales para comprar los insumos y realizar el beneficio de la misma en amplios edificios inmediatos a los cam-

41 Hamnett, "Between", 1994, pp. 39-62; Baskes, "Coerced", 1996, pp. 1-28. 
pos de cultivo. Se estima que la inversión necesaria era en promedio, de 10000 a 50000 pesos. Dado el valor de la tierra en regiones especializadas en este cultivo como fueron el valle de Cuernavaca y la zona de Cuautla Amilpas, (desde el siglo XVII se utilizaron esclavos negros, hasta 100 por cada ingenio de gran tamaño, junto a trabajadores indígenas y a trabajadores libres, organizados a veces en cuadrillas) fue una elite local la que ejerció el control de las tierras y de la comercialización del cultivo. Se considera incluso que la mayoría de estas haciendas se consolidaron alrededor de ingenios monumentales cuyos vestigios se han conservado hasta hoy en día. De hecho, y a lo largo del periodo colonial, las haciendas como las de Morelos-desde el punto de vista productivo y relación con las comunidades- experimentaron cambios continuos y muy complejos, diferenciándose unas de otras en función de las redes así constituidas. ${ }^{42}$

Es una evidencia la distinción forjada por F. Chevalier, entre un México del norte y un México del sur. El primero, de inmensos espacios que incluían tierras yermas o despobladas, "zonas de fronteras" recorridas por indios nómadas -propiedades extensas tales como las que llegaron a describir en su tiempo los virreyes Ortega Montañés (en el caso significativo de Nueva Galicia), y el conde de Revillagigedo, tan inmensas que llegan a formar

${ }^{42}$ Scharrer, "Trabajadores", 1992, pp. 149 y ss; Martin, Rural, 1985 y de la misma autora, una aproximación en términos de modos de producción, "Modes", 1992, pp. 107-121. parroquias "naturales"- y toda una franja margina de la población local; y el segundo, organizado alrededor de comunidades indígenas y campesinas estables y mejor jerarquizadas, y de haciendas más pequeñas y más especializadas en lo que a producción se refiere. Esto nos permite resaltar el hecho de que en una misma unidad terrritorial y política -Nueva España-, coexistían varios tipos de explotación de las riquezas naturales (agricultura, cría de ganado, pero también minería de la plata) y por lo tanto varios tipos de relaciones sociales y organizativas. La pregunta apunta en estas condiciones más bien a la posible intensificación de estas diferencias iniciales o a la diversificación de las consideradas como bases económicas y sociales.

Una respuesta para el norte lo constituye el ejemplo zacatecano, significativo tanto de una evolución económica como de una dinámica social original que culmina en este modelo del gran minero-hacendado ennoblecido. Otro ejemplo sumamente ilustrativo para el centro-sur, nos lo proporciona la región de Tepeaca en donde, a pesar de la relativa estabilidad de las estructuras de propiedad (la elite hacendada preservó su dominio durante un lapso de 90 años, mientras que en Guadalajara fue de 25 años) son escasas las propiedades que atestiguan una continuidad en la transmisión de los patrimonios y su correspondiente estatus social. De 1740 a 1779 , ocho haciendas cambian de propietarios; para fines del siglo XVIII, otras cinco cambian también de dueños, "y completan el proceso de desplazamiento de los antiguos linajes de hacendados" fun- 
dados en el siglo XVII en una elite regional presente en el Cabildo de Puebla. La excepción la constituyen ya en ese siglo unas pocas familias: Calderón Ladrón de Guevara, Tamayo (familia que poseyó las haciendas San Vicente y San José Capula durante 120 años) y los Gorozpe, poseedores del mayorazgo fundado a fines del siglo XVI por el obispo de Puebla don Diego Romano. A fines del siglo XVII, está en manos del bisnieto Francisco Xavier de Gorozpe. Otra rama de la familia, la de Solís-Gorozpe, formará parte de los "nuevos grupos propietarios" que sustituirá de manera definitiva, en las postrimerías del siglo, a lo antiguos linajes de hacendados. Fueron en realidad los únicos supervivientes de esa evolución que acabó con los linajes de hacendados fundados en el siglo XVII. Este caso extremo se inscribe en la larga duración de una elite regional -las fincas de esta familia estuvieron vinculadas desde fines del siglo XvII, por lo menos, hasta la década de $1850-$ y quizás sea por ello más fácil de interpretar.

De hecho, "el derrumbe financiero de las fincas provocado por la acumulación de censos fue, en la mayoría de los casos, el factor precipitante de la transferencia de la propiedad", como en la familia de los Arruti, quienes contribuyeron en este endeudamiento con dotes en favor de conventos, fundación de capellanías destinadas a miembros de la familia. Otros hacendados de "horizonte local" (base económica), y no regional como era el caso de los Gorozpe, instalados significativamente en la capital regional, Puebla, se encontraron en esta situación. Ahora bien, los grupos familiares que conformaron la elite local (recordamos que a principios del siglo XIX, diezman $67.7 \%$ del maíz sometido a ese derecho; en 1810, las doce haciendas de la elite local pagan $75.1 \%$ del diezmo del maíz y $99.6 \%$ del diezmo dol trigo) que resultó mas estable en este aspecto hasta bien entrado el siglo XIX, al adquirir algunas fincas a consecuencia de los remates judiciales y por lo tanto a un precio más que conveniente, lo que les permitió "equilibrar el riesgo que implicaba la compra de una propiedad fuertemente endeudada". ${ }^{43}$

Condiciones similares a las que se observaron para Oaxaca prevalecieron en la zona de Chalco, estudiada por John Tutino. La proximidad del mercado de la ciudad de México, con una fuerte presencia española y debilidad en los lazos comunitarios propiciaron el desarrollo de una elite de hacendados, quienes eran "los que obtenían las ganancias y sufrían las pérdidas de la agricultura en las haciendas" según la amplia definición de J. Tutino, a pesar de lo diversificadas que estuvieran sus actividades. Los dueños de las haciendas de Chalco eran en este sentido parte integrante de la elite afincada en la ciudad de México y que controlaba las redes del comercio regional y extra regional desde la capital virreinal. Un grupo cuya solidez radica precisamente en la integración perió-

43 Garavaglia y Grosso, Puebla, 1994, pl. 166-182; Young, Crisis, 1992, pp. 115-116. Sobre el diezmo en cuanto indicador de producción agrícola y la discusión de Brading, véase la crítica de Ouweneel y Bijleveld, "Economic", 1989, pp. 479-557. 
dica de nuevos miembros. En el siglo XvIII, los hacendados de la región de Chalco son empresarios recién enriquecidos, o sus descendientes inmediatos. Con la Independencia llegarán los mineros ricos y comerciantes "por políticos en busca de riqueza", modificándose de esta manera la estructura interna de esa "oligarquía agraria". ${ }^{44}$

MÁS ALLÁ DE LO ECONÓMICO: MENTALIDADES Y CIASES SOCIALES

No se trata aquí de formular ningún juicio de valor, ya de por sí frecuentes en la historiografía especializada, y esto desde los albores de la revolución de Independencia, tanto en la historiografía liberal como en la conservadora. Ahora bien, en el balance historiográfico en el que se fundó la interpretación que acabamos de presentar, se evidencia -aunque no de manera nítida todavía, habida cuenta quizás de los intereses propios de los autores, de su formación inicial, o de sus opciones metodológicas- el contraste que se da entre la modernidad ostentada por unos cuantos empresarios (minoría adelantada por no decir ilustrada como lo pone de relieve su participación final en los acontecimientos de Independencia) y los comportamientos que se observan in situ, especialmente en los lugares de origen de las referidas fortunas. Estos mismos comportamientos "señoriales"

${ }^{44}$ Tutino, "Hacienda", 1975, pp. 497-528, repròd. en Miño, Haciendas, 1991, pp. 197199. aparecen a todas luces, como lo indicamos, en los testimonios excepcionales que nos dejaron unos cuantos viajeros, funcionarios reales (virreyes, intendentes, prelados) ilustrados o no, y otros testigos, a veces extranjeros, de la vida cotidiana en el México del siglo XVIII.

El barón de Humboldt, Nicolás Lafora, o el padre Morfi insisten, ya sea en la descripción de la cárcel que simboliza en tal hacienda del norte el poder omnipresente de su dueño sobre unas yermas inmensidades (por más que él este ausente, instalado en el boato de la ciudad de México), o bien en la riqueza del traje, en el vestir, o en la arquitectura de los lugares y ciudades circundantes (edificios religiosos edificados por los poderosos amos del suelo). Asimismo subrayan la autoridad de facto que ejerce el propietario, aun por encima de las autoridades judiciales locales tales como los alcaldes - cuyo nombramiento depende con frecuencia de la benevolencia de los grandes hacendados-, de los corregidores, jueces visitadores y otros oficiales reales, problemática ligada también a los fueros nobiliarios y militares. La descripción que el padre Morfi hace del mineral de Sombrerete, resulta particularmente ilustrativa en el marco de una problemática orientada hacia el estudio de las prácticas efectivas, hacia la permanencia de los modelos culturales, de los comportamientos y estructuras mentales o sea de representaciones fundadas en una herencia hispánica. Estas aparentes contradicciones no se pueden explicar por lo tanto por el solo factor económico. Aislado, desligado de un con- 
texto global, éste no contribuye sino en empobrecer la realidad inicial, si consideramos la función social que le corresponde desde los inicios de su historia a la hacienda novohispana.

\section{La frontera como oportunidad de granjearse méritos y tierras}

Se ha comprobado que muchas mercedes de tierras, a raíz de las cuales se. fundaron las grandes haciendas de Nueva Galicia o de Nueva Vizcaya, se otorgaron con motivo de los servicios militares prestados a favor de la corona en las zonas de fronteras. Si bien la consolidación de las haciendas propiamente dicha se dio en el siglo XVIII, con base en fundaciones ocurridas en el siglo anterior, también hay que señalar que muchos de los latifundios novohispanos se fundaron en este siglo. Tal fue el caso de los dominios novogalaicos de los condes de Santa Rosa, Santiago de la Laguna, San Mateo Valparaíso. Sendos personajes intervinieron en varias oportunidades en las "fronteras" locales (Tepic, Colotlán) pacificando a los indios rebeldes, armando ejércitos particulares a su costa, fundando iglesias y siguiendo en esto la línea de la conquista espiritual de México (en San Andrés del Teúl en 1720, el futuro conde de San Mateo, Fernando de la Campa Cos, funda dos "poblaciones", edificando allí dos iglesias) reclutando más tarde a la mano de obra indígena para trabajar en sus haciendas. Este proceso encaminado a preservar las propiedades locales de las incursiones de los indios o del abigeato, y hacer más seguros los "caminos de la plata", se registra incluso hasta principios del siglo XIX para esta misma región. Los descendientes de los "conquistadorespobladores", incluyendo la dinastía criolla de los Fagoaga, defiende a su costa la paz y la tranquilidad en la comarca zacatecana. ${ }^{45}$

El caso más excepcional, por ser el más extremo tanto en sus fundamentos como en las consecuencias derivadas en todos los niveles, quizás sea el del conde de Casafiel, un ejemplo sin embargo desconocido por los trabajos que contemplaron los orígenes de la nobleza novohispana. Fundados a principios del siglo XVII, los pueblos de guachichiles de San Sebastián del Venado ("república de Indios") y San Jerónimo de la Hedionda siempre habían sido rebeldes, oponiéndose -como lo subraya A. de la Mota y Escobar- a los españoles de manera constante. Ambos pueblos, que quedaban a proximidad de las Salinas del Peñol Blanco, pertenecían a la Alcaldía mayor de Charcas. Ubicados a poca distancia de la ciudad de San Luis Potosí, y de las haciendas del marqués de Rivas Cacho (Guanamé), estuvieron por lo tanto en el centro de los tumultos que sacudieron en mayo y julio de 1767 la capital regional, al igual que otras ciudades novohispanas como Guanajuato, San Luis de la Paz o Guadalcázar. A los motivos de orden fiscal que provocaron estas sublevaciones se añadió, en junio del mismo año, la expulsión de los jesuitas. Los dos pueblos tomaron parte activa en

${ }^{4 s}$ Langue, Mines, 1992, pp. 188 y ss. 


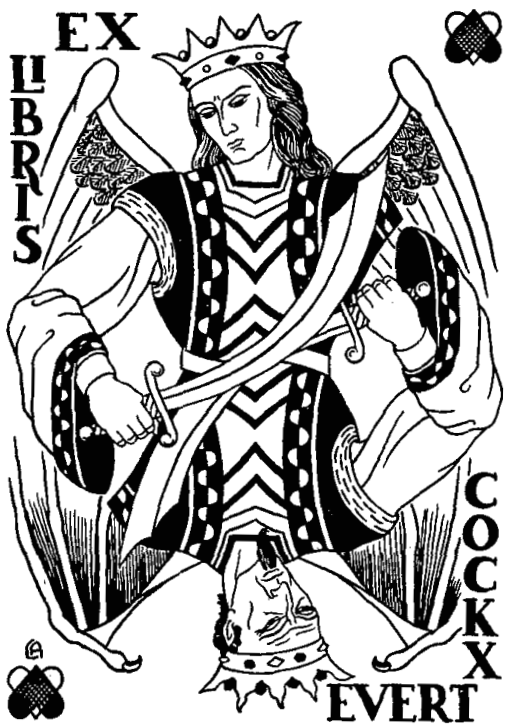

este alboroto, a raíz del cual intervino Francisco Xavier de Aristoarena y Lanz, alcalde mayor asentista de las Salinas (puesto que había "heredado" de su tío), justicia mayor "proveedor a paz y a guerra", teniente de capitán general del rey en estas tierras de frontera que comprendían asimismo los alrededores de Charcas y de Sierra de Pinos. Hacendado (en el valle de Valparaíso) y minero, Aristoarena fue en dos oportunidades alcalde de segundo voto de Zacatecas, alcalde de primer voto de la misma ciudad (aunque también poseía fincas urbanas en la ciudad de México). Casado con una representante de una aristocrática familia de la región, María Guadalupe de la Campa Cos, era uno de los ha- cendados de mayor prestigio en el sur de Nueva Galicia. ${ }^{46}$

Sin embargo, Francisco Xavier de Aristoarena adquirió los méritos y servicios que nutren la llamada "relación de méritos y servicios", presentada con el fin de conseguir título nobiliario, con motivo de la sublevación de estos dos pueblos de indios. Encargado por el virrey Marqués de Croix de pacificar la zona, armó a su costa a 200 hombres y convocó a los alcaldes de las localidades vecinas (Charcas, Pinos). En los dos meses que duró su intervención, mantuvo no sólo a este ejército privado (hueste) sino también a cuatro o cinco compañías provinciales que se le habían enviado desde San Luis Potosí y otras jurisdicciones (es decir, 800 soldados):

ministrando dos o tres reses cada día para ellos, manteniendo en tres parajes cocineras, las que en dicho tiempo guisaron comida y cena para dichos soldados, ministrándoles también cle cuatro a cinco fanegas de maíz cada clía.

Hasta la ejecución de los cabecillas, las horcas y maderas resultaron a cargo del futuro conde de Casafiel, quien no se conformó con pacificar la región: empezó a empadronar a los indios rebeldes y a exigirles el pago del tributo, y no vaciló en incorporar buena parte de los bienes de las cofradías (bienes de ganado) en el patrimonio real; asimismo repartió y adjudicó las tierras comunales entre vecinos "hon-

46 Jiménez, Haciendas, 1989, p. 37 y ss; Langue, "Minero", 1987, pp. 173-193 y "Convergencia", 1990, pp. 14-17. 
rados y pobres" con el fin de contener en adelante las "sediciones" de la población indígena. Fue a raíz de esta intervención, debidamente aprobada por el visitador y entonces ministro de Indias José de Gálvez, cuando se le otorgó expresamente el título de conde de Casafiel (1776). Francisco de Aristoarena dista de ser una excepción en el mundo de la nobleza novohispana, ya que es sólo un ejempło particularmente llamativo de un proceso que abarca el periodo colonial en su conjunto y que sin embargo hace recordar en muchos de sus aspectos el proceso de reconquista tal como se dio en la metrópoli. Basta con recordar en ese aspecto los dos impuestos que se les cobraban a los titulados, el de lanzas (en caso de creación o de sucesión a un título nobiliario) y el de media-annata, y la consiguiente evolución semántica de los mismos. Hay que indicar, sin embargo, que este modelo peninsular experimenta algunos cambios conforme avanza el siglo XviII, a medida que, de la noción de "servicio militar" que estos grandes hacendados le prestan al soberano, se pasa paulatinamente a la noción de "servicio financiero" (implícito de por sí cuando un hacendado arma un ejército privado); éste va a ser precisamente el mayor argumento de las elites económicas de fines de siglo, y especialmente de los Fagoaga, dinastía de "banqueros de la plata", y proveedores de préstamos y donativos diversos a favor de la Corona española, a la hora de solicitar título nobiliario. ${ }^{47}$

${ }^{47}$ Langue, Mines, 1992.

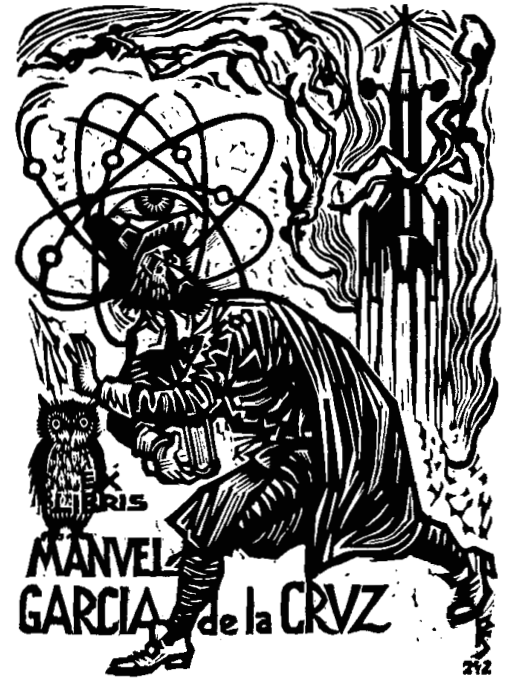

Las inversiones sociales y el afán de nobleza

Este tipo de referencias contribuyen sin lugar a dudas a entender mejor el desarrollo en tierras americanas de una aristocracia señorial que goza de inmunidades de marcado carácter medieval (fueros militares -los interesados son sistemáticamente capitanes de frontera o de milicias urbanas- y nobiliarios, que terminan siendo confundidos en la persona de los grandes mineros-hacendados ennoblecidos), y tiene poder de justicia en sus dominios, amén del poder de hecho de que hacen uso, gracias a sus clientelas, en el conjunto de las provincias donde se encuentran sus haciendas. Recordemos que este derecho de justicia im- 
plica ocasionalmente prácticas expeditivas como la que consistió en darle latigazos a un cochero, según la descripción que nos proporciona Manuel Payno. Por ser obra de ficción, la aportación de Payno recoge en realidad hechos de la vida real que sólo de manera excepcional, aparecen a todas luces en los documentos de la época. ${ }^{48}$ En este sentido, las inversiones sociales que representan la compra de un título nobiliario y el correspondiente "afán de hidalguía/nobleza" - para retomar la expresión acuñada por Fernand Braudel- resultan ser al mismo tiempo culminación de un proceso y nuevo punto de partida para el personaje y sobre todo la memoria de la estirpe así consagrada.

Ahora bien, como se ha vislumbrado a lo largo de este trabajo, las estrategias económicas constantemente corren parejas con inversiones sociales -de manera general con una búsqueda de un estatus social relevanteen que las más significativas y las más anheladas son las otorgaciones de títulos de nobleza y también los hábitos de las órdenes militares, eso que G. Lohmann Villena no vacilaba en calificar precisamente de "órdenes nobiliarias". Recordemos en esta perspectiva que la mayoría de los títulos nobiliarios de América se otorgaron en el siglo Xvili, y 16 de los 49 registrados lo fueron a favor de unos mineros-hacendados (diez a unos comerciantes). Ocho de los títulos creados en la segunda mitad del siglo XVIII están relacionados de manera directa o indirecta con la región zacatecana, por

${ }^{46}$ Payno, Bandidos, 1945. medio de las inversiones realizadas en el campo de la minería o incluso con motivo de los vínculos de parentesco establecidos con los grandes mineroshacendados de la primera mitad del siglo. Tal es el caso por ejemplo del conde de San Mateo Valparaíso (1727) al que se asocia en la segunda mitad del siglo el título de marqués de Jaral de Berrio (1774); del marqués del Apartado (familia Fagoaga, 1771), del conde del Valle de Súchil (1776), del conde Casafiel (1777), del conde de Casa Rul (1804) o de Pérez Gálvez (1805) etc. Hay que recordar por otra parte, que la mayoría de los grandes mineros de Zacatecas y de Guanajuato eran caballeros de una orden militar (Fagoaga, Rétegui, etc.), que era la primera forma de nobleza, preferentemente la de Carlos III en el último tercio del siglo, realizando en su persona la unión de la vocación militar (los mineros zacatecanos disponen de verdaderos ejércitos privados) y del predominio económico-financiero. ${ }^{49}$

Ahora bien, siguió vigente el modelo aristocrático peninsular, a través del sistema de valores (este mismo que condiciona la búsqueda de títulos nobiliarios), en otros términos, este "afán de hidalguía" para el mundo mediterráneo, y por lo tanto del "estilo de vida" propio de este "tipo social original". Las manifestaciones de este estilo de vida propio de estos grandes hacendados aristócratas son a grandes rasgos las siguientes:

a) En primer lugar, la permanencia del concepto de honor, tal como lo estudió J. Pitt Rivers para el mundo

${ }^{49}$ Langue, Mines, 1992. 
mediterráneo. ${ }^{50}$ Hay que recordar en ese aspecto que no había ninguna contradicción entre el ejercicio de la profesión de minero y la otorgación de un título de nobleza, como lo senaló en 1783 Aranda, ministro de Carlos III, al referirse precisamente a los "fueros" del gremio minero y a pesar de la situación poco evolutiva que se observaba en el mismo momento en la propia metrópoli.

b) La búsqueda de "honores adicionales", relacionada en especial con la esfera de lo político (cargos municipales, diputaciones de minería, participación en la dirección del mismo Tribunal de Minería en la ciudad de México, o en el Consulado de comercio de esta ciudad). Varios de estos aristócratas llegan a ser incluso regidores del cabildo de la ciudad de México, como el marqués de Jaral en 1805-1806..$^{51}$

c) Las extensas redes de clientes, "paniaguados" y otros "allegados", de familiares que sirven los propósitos económicos más elaborados, acaparando por ejemplo minas y tierras como fue el caso con el conde de San Mateo, calificado por sus detractores de "tirano de Nueva Galicia". Esto nos lleva indudablemente a la problemática de las formas de sociabilidad que prevalecen en esta sociedad de Antiguo Régimen. ${ }^{52}$ El hacendado se desempeña por lo tanto como padrino,

${ }^{50}$ Pitt-Rivers, Anthropologie, 1983, passim.

${ }^{51}$ Langue, Mines, 1992, p. 260.

52 Véase sobre esta dualidad característica de los grandes mineros zacatecanos, sus modalidades e implicaciones a finales del siglo XvII, en Langue, "Mineros", 1991, pp. 327-341. protector (es el papel fundamental de la relación de compadrazgo tal como se establecía en este caso), de unas redes de allegados y por lo tanto de una clientela, aunque no por eso se califican estos comportamientos de "patriarcales". En esta perspectiva, resulta más adecuado evocar "el matiz patriarcal en las relaciones sociales", tal como lo describe E. van Young para la vecina región de Guadalajara. Se trata en realidad de un verdadero sistema de valores, trasladado a tierras americanas y ejemplificado en esta parte norte de Nueva España. De ahí también el hecho de que el término "feudal" no alcance a definir con toda propiedad una realidad compleja de por sí y la importancia que adquiere la antropología histórica a la hora de aproximarse a estos fenómenos: describir lealtades, vínculos de parentescos, estrategias de alianzas, etcetéra. ${ }^{53}$

Esta relación de lealtad que unen los trabajadores de haciendas a los amos del suelo no es exclusiva de otras regiones. E. van Young señala en efecto que, en Guadalajara, "la imagen de un terrateniente o de su administrador cabalgando a la cabeza de una banda armada de los dependientes" no era nada excepcional durante las primeras etapas de la rebelión, "lo que tiene un claro sabor feudal". De manera inversa, el control social que ejercía el hacendado conforta el papel impartido a las grandes poblaciones (de residentes, permanentes o no) que son las haciendas: éstas asumen en este sentido el papel de "pueblos

53 Langue, Mines, 1992; Young, "Mexican", 1983, p. 149. 
subrogados", influyendo sobremanera en el debilitamiento de la estructura social de las comunidades indígenas vecinas y en su "secularización" si consideramos los trabajos de historia rural más recientes. Y no faltan ejemplos a favor de esta interpretación aparentemente inusitada. En 1794, se registra ante la Audiencia de Guadalajara una queja del alcalde indígena del pueblo de Buenavista, cerca de Lagos (Guadalajara): decía que los vecinos españoles de la jurisdicción "solían tener a los indios viviendo y trabajando en sus haciendas, de modo que éstos no reconocían las pretensiones del pueblo" y se negaban en especial a reconocer su autoridad, a contribuir con los gastos de fiestas, a trabajar en las casas de comunidad o para la iglesia e incluso a aceptar cargos en el referido pueblo. Los propios funcionarios del pueblo con dificultad lograban cobrar los tributos de los residentes en las haciendas, quienes decían pertenecer en este caso al pueblo y cobrar sus sueldos solamente cuando el hacendado quería; este último era muy poco cooperativo con los mencionados funcionarios. ${ }^{54}$

d) Cuarta característica: la endogamia nobiliar, de manera general las estrategias económico-matrimoniales que confortan el poder económico de la elite hacendada ya que los cónyuges se elijen dentro de un grupo social muy restringido.

Como lo señaló acertadamente John Kicza, las estrategias realizadas

\footnotetext{
54 Young, Ciudad, 1989, pp. 152 y 276. Véase del misno autor, "Hinterland", 1992, cap. IV.
}

para medrar, para hacer fortuna, o sea adquirir un poder económico y un estatus social relevante (minería, comercio), difieren mucho de las estategias ideadas para preservar este estatus y el patrimonio correspondiente (inversiones en la tierra). Las bases económicas de la nobleza mexicana descansan predominantemente en la hacienda, si consideramos la lista establecida por Doris Ladd. La mayoría son hacendados: marqués del Valle de Oaxaca (título otorgado en 1529), de Miravalle (1690), de Guardiola (1691), de Prado Alegre 1772.5 Y si no lo son, lo llegan a ser: los grandes mineros invierten sistemáticamente en las tierras: tal es el caso de los marqueses de San Clemente (1730), del conde del Peñasco (1768), de los marqueses de Jaral o de Rayas (1774), del marqués de Vivanco (1791), del conde de Alcaraz (1797), o del conde de Pérez Gálvez (1805). Está por demás señalar que los grandes comerciantes adoptan la misma estrategia: el conde de Jala (1743) y el de Rivas Cacho (1764), de Rábago (1774), o de Tepa (1775). Aunque sólo tres de estos aristócratas logran reunir en su persona y en su familia las tres actividades: los marqueses de Aguayocondes del Alamo (títulos creados en 1632 y 1734 respectivamente), el conde de Regla (1768) y los marqueses del Apartado (familia Fagoaga, 1771), son también banqueros financieros. Entre los latifundios poseídos por estos nobles, y que tienden a preservar estas prácticas endogámicas, mencionaremos sólo los más importantes,

ss Ladd, Mexican, 1976, p. 28. 
que por varios motivos pasaron a la historia: la Gavia, Santa Lucía y Jalpa (México) propiedades del conde de Regla; la hacienda de Chapingo, del marqués de Vivanco; la de Presa de Jalpa, del conde de la presa de Jalpa (Bajío); las haciendas de Jaral y de San Felipe del marqués de Jaral, la célebre Ciénega de Mata del marqués de Guadalupe; Bocas en San Luis Potosí, propiedad del conde del Peñasco, Tetillas en Fresnillo, del conde de Casa Rul; mientras los condes del Álamo, marqueses de Aguayo reinaban sobre San Pedro del Álamo, Patos, Parras, Santa Catarina y Cuatro Ciénagas. Símbolo por excelencia del estatus social logrado, el título nobilario siempre recoge el nombre de una finca, nunca de una mina o solamente en el caso de los "títulos previos"; a la otorgación del título nobiliario. ${ }^{56}$

Resulta particularmente llamativa esta tendencia de los empresarios de invertir en las haciendas (la tierra aparece como elemento, o mejor dicho, como fundamento y garantía del estatuto social y del prestigio que conlleva) y de manera inversa -característica de la elite novohispanaestablecer enlaces con los nuevos ricos. Las genealogías estudiadas por Doris Ladd corresponden a 32 familias de este tipo (elite principal con títulos nobiliarios); a fines del siglo XVIII, por lo menos 17 de ellas se alían con el "nuevo capital" (de esta manera los hacendados evitan recurrir al crédito con intereses). Los condes del Valle de Orizaba, dueños de la ha-

56 Langue, Mines, 1992. cienda La Asunción en Chalco (entre otras propiedades) encabezan de esta manera un clan de la elite regional, en el cual figuran comerciantes aliados con la familia de los condes, a veces desde finales del siglo XVII: entre ellos Miguel de Lugo y Terreros y Bartolomé Terreros y Trejo, también hacendados en Chalco. Otra familia que supo unir la riqueza empresarial con la herencia aristocrática (nobiliar y agraria) fue la de los condes de Jala: Joaquín Gómez de Pedroso, dueño de la hacienda del Moral, su primo el conde de San Bartolomé de Jala y un pariente político, el marqués de Rivascacho habían heredado según J. Tutino, una fortuna comercial amasada durante el siglo XVIII e invertida en haciendas, como en Chalco, donde llegaron a dominar el mercado de cereales.

Otro ejemplo tan significativo de estas alianzas económico-matrimoniales nos lo proporcionan las estrategias desarrolladas por la condesa de Miravalle. María Magdalena Dávalos y Orosco, viuda heredera del título y del mayorazgo de los condes de Miravalle, quien había heredado cuantiosas deudas que le valieron un "arresto domiciliario" en los años 1734-1735. Refugiada en la ciudad de México (había dejado sus haciendas poco rentables en la región fronteriza de Compostela y de Tepic, pero también otras más rentables en el Valle de México, en Tacuba y en Michoacán (haciendas azucareras heredadas de su abuela materna), preservó el estatus social de la familia, resarció incluso su prosperidad por una cuidadosa administración de las fincas rurales y urbanas; clesa- 
rrolló en especial un área de su "cartera" de producción agrícola, fomentando la producción de pulque, maíz y trigo en las haciendas del valle de México, así como la cría de ganado en Compostela y Tepic para abastecer a la ciudad de México en carne y cueros, diversificando de esta manera sus intereses y protegiéndose de la saturación de los mercados. Asimismo logró incorporar a sus hijos en la carrera burocrática, en el Tribunal de la Cruzada, y en el Cabildo de la ciudad de México, y casó a una hija -María Antonia- con el minero y hacendado Pedro Romero de Terreros (quien se hizo en esa oportunidad compadre de la condesa) en una especie de "asociación comercial familiar" según la expresión de Edith Couturier. Así se realizó el intercambio de la riqueza de un hombre sin posición noble con el linaje sobresaliente de una aristócrata. ${ }^{57}$

Lo que caracterizamos como "inversiones sociales": desde las manifestaciones de piedad y caridad, construcción de templos, como por ejemplo la catedral de Zacatecas o la iglesia Santa Prisca en Taxco, y de varios santuarios locales, conventos (como el de Guadalupe en Zacatecas, donde hoy en día se conservan todavía los retratos de los bienhechores del siglo XVIII), hospitales, escuelas de primeras letras, hasta aspectos más suntuarios, perceptibles en la estructura interna de las haciendas: la existencia de palacios en la capital regional y sobre todo en la capital, virreinal, característica

${ }^{57}$ Ladd, Mexican, 1976, pp. 320-368; Couturier, "Viuda", 1992, pp. 327-363. de las "grandes familias" que residen en sus palacios de la ciudad de México, y en general de las diversiones de estos grandes mineros. ${ }^{58}$

El vuelco no se va a presentar sino con las reformas borbónicas y más particularmente con la reestructuración administrativa y política que se da a raíz de la creación de las intendencias (1786 para Nueva España). Estas reformas acaban, pero en parte solamente, con el poder local aparatoso de los "reyezuelos", imposibilitando -por unas cuantas décadas- acontecimientos como los que se desencadenaron en el marco de la visita de un Francisco de Echávarri en los años 1730 (el visitador experimentó cuantiosas dificultades para llevar a cabo su visita de Zacatecas, con motivo de la oposición del conde de San Mateo Valparaíso, de sus parientes y clientes). Se impone en adelante la eficiencia de las estructuras burocráticas metropolitanas y se pone un freno a la delegación de poder tal como la concebían los predecesores de Carlos III (la cual funcionaba, sin embargo, en el marco de la relación de doble sentido entre el soberano y la nobleza) y a la exitosa pero peligrosa convergencia de los intereses del Estado y de los intereses de estos poderosos particulares.

\footnotetext{
58 Brading, "Mexican", 1970, p. 283; Ortega y Pérez, Estudios, 1902; Kicza, Indian, 1993; Chevalier, Formación, 1982, passim; Lohmann, Americanos, 1947; Sanchiz, Hidalgos, 1976.
} 
Los mayorazgos

En lo referente a esta institución social algunas cuestiones surgen en primera instancia. ¿Constituyó realmente la formación de los mayorazgos un factor de estancamiento del "mercado" de la tierra, la culminación de hecho del proceso de acaparamiento de tierras o en todo caso de adquisición en gran escala de terrenos (tal como lo dejaron a entender no pocos altos funcionarios y arbitristas del siglo de las Luces)?, io tiende fundamentalmente a reforzar el prestigio nobiliario, si nos referimos a las solicitudes presentadas ante el monarca con el fin de establecer un vínculo ("vínculo y mayorazgo" según la terminología oficial), lo que nos indica por otro lado cuál podía ser el fundamento efectivo de estas creaciones (prestigio que conlleva la posesión de tierras)? Hay que recordar que en el siglo XviI estas creaciones se multiplican, de tal forma que la corona tuvo que adoptar medidas drásticas e imponer limitaciones para controlar el fenómeno. Bien se conoce-aunque poco se ha estudiado- la Real Cédula de 1795, que eleva el nivel de fortuna requerido para fundar un mayorazgo. En Zacatecas, pudimos demostrar que tal fue el camino elegido por los grandes mineros-terratenientes, donde las familias más pudientes llegaron a formar hasta tres vínculos de este tipo, en las postrimerías del siglo, o sea en el preciso momento en que se dificultaban ya sobremanera estas iniciativas.

Para estos grandes mineros-hacendados, la tierra reconcilia inversiones sociales y económicas y desempeña un papel esencial de preservación de un patrimonio nobiliar. De ahí las múltiples fundaciones de mayorazgos que se registran en Nueva España. Desde los mariscales de Castilla (ocho mayorazgos); los condes de Santiago-Calimaya y los de Regla (tres cada uno); condes de San Mateo Valparaíso-marqués de Jaral-de San Roman, tres; Aguayo dos, y presa de Jalpa dos. Cuando el conde de Regla compra en 1777 las haciendas del antiguo colegio jesuita de San Pedro y San Pablo (Tepozotlán) en 1000000 de pesos aproximadamente, y más adelante las haciendas de Santa Lucía, Jalpa (en 500000 pesos) y La Gavia, se alía en el mismo tiempo con el conde de Jala, comerciante español, quien se casa con su hija. La extensión de la fortuna del conde en bienes raíces, está atestiguada por la fundación de tres mayorazgos: dos estarán ligados a otros títulos nobiliarios (marqués de San Cristóbal o de San Francisco). El valor de los vínculos fundados por los grandes hacendados oscilaba de 27600 pesos a más de 1000000 de pesos, mientras el valor de las fincas rurales de los fundadores pasaba con frecuencia de los 100000 pesos. Recordemos por ejemplo que la hacienda de Jalpa, en 1775, cuando cra propiedad del conde de Regla, valía 575830 pesos; el mismo año, se valoraba la hacienda de Guanamé, propiedad del conde de Pérez Gálvez (Zacatecas) en 485068 pesos; Tetillas, del Conde de Casa Rul valía 784560 pesos (1807); Parras y Patos, del marqués de Aguayo 1057520 pesos (1750), más los 640518 pesos de Nuestra Señora del Rosario de Bonanza y los 
61465 pesos de la hacienda de San Pedro del Álamo, vinculada a este título, para mencionar tan sólo los ejemplos más llamativos. ${ }^{59}$

El latifundio de San Pedro del Álamo fue de hecho el más grande de Nueva España: alcanzaba 5946813 hectáreas según Harris (la extensión actual del estado de Coahuila es de $150295 \mathrm{~km}^{2}$ ). Había sido fundado en el siglo XV por Francisco de Urdiñola, capitán de frontera, y gobemador de Nueva Vizcaya, beneficiado con mercedes de tierras por la pacificación de esta región. Una de sus herederas, Francisca de Valdés, casaría con Agustín de Echevers, fundándose así el primer mayorazgo en España (1693, en Pamplona). De este mayorazgo heredaron Ignacia Javiera de Echevers y José de Azlor, hijo segundón del conde de Guara. Segunda etapa en la constitución del latifundio: el título de composiciones de tierras se expidió a favor de los marqueses en 1717. Legitimaba por lo tanto la posesión del latifundio que se extendía entre Saltillo y Parras y al sur, hasta la hacienda de Bonanza en los límites de Zacatecas o sea más de 800 sitios de ganado mayor y menor. De ahí la fundación del segundo mayorazgo en 1727, efectuada siempre en España y a raíz de los servicios prestados por José de Azlor durante la expedición a Texas. El tercer mayorazgo, perteneciente a los condes de San Pedro del Álamo fue fundado en 1735 por Francisco de Valdivieso, primer poseedor del título nobiliario. Como lo

59 Ladd, Mexican, 1976, pp. 44, 74, 77; sobre estos mayorazgos, véase la síntesis de Vargas-Lobsinger, Formación, 1992. indica María Vargas Lobsinger, al analizar esta historia excepcional, el endeudamiento y las utilidades bajas de las haciendas, la promulgación de la Real Cédula de 1804, llamada de Consolidación de Vales Reales, así como el desencadenamiento de un conflicto familiar, fueron las causas principales de la decadencia de una fortuna que subsistió casi durante 250 años. El latifundio de San Miguel del Aguayo fue vendido en el México independiente a la familia Sánchez Navarro antes de ser dividido por el gobierno del presidente Juárez.

\section{A MODO DE CONCLUSION: LA HACIENDA NOVOHISPANA Y EL PROCESO DE INDEPENDENCIA}

Cabe una última pregunta: ¿cómo caracterizar a los hacendados que acabamos de mencionar, empresarios muchos de ellos, dueños de la tierra exclusivamente y "señoritos" otros tantos? ¿Como oligarquía? Para la segunda categoría, algo carente de dinamismo, quizás pueda ser ésta la caracterización más apropiada, dada la unicidad de sus inversiones. Para la primera, en cambio, nos rehusamos a utilizar un término, connotado además de manera negativa en la historiografía del siglo XIX y XX. Tanto la diversificación de sus intereses económicos y cl grado de integración de los mismos, como las estrategias elaboradas con el fin de preservar un estatus social relevante, o las modalidades de su participación en los mercados regionales, "nacionales" o supranacionales, nos lleva a rechazar la visión unilateral de la hacienda novohispana que encierra esta definición. 
Se trata en efecto de una elite empresarial con intereses económicos diversificados, lo que es la razón de ser y la condición al mismo tiempo de su existencia y más todavía, de su inscripción en la larga duración, que determina su estatus de elites "principales". Una elite que, al mismo tiempo, no deja de desempeñar un papel de "intermediario cultural", en la medida en que reúne en unos mismos personajes una modernidad ejemplificada en la economía local y una tradición de raigambre hispánica en lo social. Lo confirman de cierto modo las modalidades y las incertidumbres de su participación en los acontecimientos de la Independencia. Resulta difícil valorar las motivaciones de los distintos grupos sociales, por más que se hayan multiplicado los estudios regionales: escasas son en efecto las fuentes que realmente permitirían precisar este panorama. Ahora bien, la cuestión de la tierra subyace en muchas de las actitudes presentadas en esa oportunidad, aunque no se llegó a mencionar siempre de manera explícita. En Guanajuato, es notable la participación de indígenas despojados de sus tierras, jornaleros o peones de haciendas y en las zonas mineras en general, de los traba. jadores de minas (Zacatecas). A pesar de las ideas avanzadas por unos cuantos representantes de las luces (Revillagigedo, Abad y Queipo), el problema de la tierra, sin embargo, nunca llegó a constituir una reivindicación en sí y a plasmarse en la legislación nacional, sino hasta las leyes de Reforma. Sobre la economía colonial en su conjunto además de la sombra del empobrecimiento, si retomamos los análisis de E. van Young en este sentido, empobrecimiento factor y resultante a la vez de mala distribución de la riqueza que "parece haber marcado el final del periodo colonial", y en consecuencia generador de tensiones sociales. En otros términos, y según este mismo autor, la "proletarización", es decir, la asimetría en la distribución de la riqueza a fines del periodo colonial, llegó a ser el

complemento de una participación creciente en el mercado, de parte de las grandes propiedades; la brecha cntre el poder adquisitivo real de la masa de la población y los precios crecientes debe haberse ampliado lógicamente a medida que se incrementaban las ganancias de la agricultura a gran escala

en beneficio de unas elites regionales como sucedió en Michoacán o en Guadalajara ${ }^{60}$ Está por demás decir que este tipo de interpretación, si bien se funda en datos estadísticos y archivísticos debidamente comprobados, no siempre coinciden con estudios de tipo sociocultural tal como los llegamos a definir anteriormente. Quizás haya en esta perspectiva que mantener la diferenciación establecida entre los dos Méxicos, en cuanto factor explicativo de gran parte de las dinámicas coloniales que se observan tanto a nivel económico propiamente dicho, como desde el punto de vista social y cultural.

${ }^{60}$ Young, "Ricos", 1992, p. 44 y "Hacia", 1992 , pp. 305 y ss., así como los otros capítulos de esta obra donde se contemplan las relaciones en la difusión del milenarismo y los inicios de la revuelta popular. 
Sin embargo, la prolongada inestabilidad económica y las sublevaciones, dicho de otra manera, la "profunda desarticulación de la sociedad mexicana hasta el nivel de los pueblos" (E. van Young) socavaron en parte las bases regionales de las elites hacendadas. Los conflictos originados por la propiedad de la tierra dieron paso en algunas oportunidades a rebeliones, en Tlaxcala, Puebla, Atlixco, en el perímetro de la Audiencia de México (quizás por su proximidad con la capital virreinal), también en la Intendencia de Guadalajara, donde los gañanes en los años 1770 habían tenido el apoyo del virrey y de la Audiencia en defensa de sus tierras de labor. Hay que señalar en ese aspecto el bando del virrey Bucareli que reglamenta las condiciones de trabajo en las haciendas y se remonta, no por casualidad, a los años 1773 y 1779. En el Bajío también se dieron casos de reclamos en este sentido y más cuando la expansión demográfica hacia imprescindible el recurso a las tierras comunales. En 1809 sin embargo, los indígenas del distrito de Cholula, después de litigar en vano, volvieron a ocupar las tierras de la hacienda de Portezuelo, desatando las críticas del célebre intendente Manuel Flon en contra del empeño de los campesinos en defender sus derechos. Otro tanto sucedió el mismo año en Guanajuato: los naturales de Xichú (Sierra Gorda), afectados por la crisis de los años 1785-1786, ocuparon las tierras reclamadas. La insurrección de septiembre de 1810 , y la toma de San Luis Potosí animó a los indígenas a que se incorporasen en las filas de la insurrección. El veredicto final, trans- mitido por el virrey Calleja en mayo de 1814, consistió sin embargo en la aprobación del fallo de la Audiencia, a pesar de las protestas del administrador de la hacienda La Parada, capitán de dragones realistas, convencido de que habían invadido sus tierras. ${ }^{61}$

Para concluir con un caso similar, pero de una estirpe de hacendados aristócratas que se perpetuará aunque de manera algo simbólica hasta nuestros días, hay que señalar que una de las consecuencias de estos litigios y de la presión ejercida por los campesinos en la proximidad de las haciendas (no siempre llevaron a la creación de un pueblo como sucedió en la hacienda de Cos, en la región zacatecana) llevó a sus dueños a que cercaran los límites de las haciendas (proceso que no deja de recordar de alguna forma las enclosures europeas). El conde de San Mateo Valparaíso, también heredero en ese momento del título de marqués de Jaral, invirtió cuantiosas sumas de dinero en cercar sus propiedades, en perjuicio de los derechos comunales. De ahí el pleito que se inició en el norte de la Intendencia de Guanajuato con la villa de San Felipe, sobre tierras y derechos afines (fundamentalmente de agua). Un grupo de tributarios había empezado a sembrar maíz en el "ejido" conocido bajo el nombre de Rancho de Bravo. En 1809 sin embargo, la hacienda de Jaral se benefició de una decisión legal a su favor y los administradores (el de Jaral y de la otra

${ }^{61}$ Tutino, "Españoles", 1991, pp. 202-203; Hamnett, Roots, 1986, pp. 86-87; Young, "Haciendo", 1991, p. 451. 
hacienda vecina, la de Huisache, también propiedad de la dinastía de los condes de San Mateo/marqués de Jaral) instalaron ganado en los sitios litigiosos. El marqués de Jaral sostuvo que eran suyas estas tierras, apoyado en este reclamo por la Audiencia, y haciendo caso omiso de la actitud contraria manifestada por el arzobispo-virrey Lizana. El inicio de la insurrección en septiembre, en Guanajuato precisamente, impidió que el aristócrata preservara "sus" derechos de propiedad. Otro tanto sucedió en Guadalajara aunque en forma más radical -reforzada en los años 1810 por la presencia de las fuerzas realistas- en la región comprendida entre el lago de Chapala y el de Zacoalco, habida cuenta de la extensión lograda por las haciendas de las familias Porres Baranda, Vizcarra y Echaurri (dueños de la hacienda de San José de Gracia) desde los años 1770. En el sur de Zacatecas, en Jerez y Apozol, las reivindicaciones de las comunidades se expresaron tan claramente aunque no de manera uniforme (con motivo de las divisiones internas) a partir de los años 1760 . Brian Hamnett insiste en ese aspecto en la capacidad de "autodefensa" de la hacienda novohispana, independientemente del poder colonial, mientras los campesinos agraviados se convertían en los soportes más firmes de la insurrección, sin que por esto se pueda hablar de acontecimientos precursores de la revolución de 1810. Estos hechos quizás expliquen por qué unos individuos o unas comunidades llegaron a unirse a las filas insurgentes después de septiembre de 1810 , en un contexto fragilizado por la crisis de subsisten- cia de 1808-1810. Con la revolución de Independencia no terminó sin embargo la historia de las haciendas coloniales ya que la "elite de transición" que describe J. Tutino, o sea la elite política de la Independencia, iba a seguir con firmeza las mismas pautas de inversiones en las tierras, reproduciendo con escasas diferencias el tan controvertido modelo social de sus antecesores. ${ }^{62}$

\section{BIBLIOGRAFÍ}

-Altman, Ida y John Lockhart (comps.), Provinces of Early Mexico, UCLA, Los Ángeles, 1976.

-Andrien, K. y L. Johnson, (comps.) The political economy of Spanish America in the Age of Revolution 1750-1850, University of New Mexico Press, Albuquerque, 1994.

-Artis Espriu, G. et al., Trabajo y sociedad en la bistoria de México siglos XVIXVIII, SEP, México, 1992.

-Assadourian, Carlos Sempat, El sistema de la economía colonial. El mercado interior, regiones $y$ espacio económico, Editorial Nueva Imagen, México, 1983.

-Bakewell, Peter, Mineria y sociedad en el México colonial en Zacatecas 15461700, FCE, México, 1976.

-Barrett, Ward, La hacienda azucarera de los marqueses del Valle (1535-1910), Siglo XXI, México, 1977.

-Baskes, Jeremy, "Coerced or voluntary? The repartimiento and market participation of peasants in late colonial Oaxaca", Journal of Latin American Studies, 28 de febrero de 1996, pp. 1-28.

${ }^{62}$ Hamnett, Roots, 1986 , pp. 92-95. Sobre Guadalajara, véase el estudio de Serrera, Guadalajara, 1977 y de Lindley, Haciendas, 1987; Jiménez, Haciendas, 1989, p. 197. 
-Bauer, Arnold J. "Rural works in Spanish America: problems of peonage and oppression", Hispanic American Historical Review, vol. 59, núm. 1, febrero 1979.

-, "Iglesia, economía y Estado en la historia de América Latina" en Martínez López-Cano, Iglesia, 1995.

-Bertrand, Michel, Grandeur et misère de l'office. Les officiers de finances de Nouvelle-Espagne, París, Publications de la Sorbonne, en prensa (Thèse d'habilitation Université de París I, 1995, 2 vols.).

-Brading, D. A., "Mexican silver-mining in the eighteenth century: the revival of Zacatecas", Hispanic American Historical Review, vol. I, núm. 4, 1970, pp. 665-689.

Mineros y comerciantes en el México borbónico 1763-1810, FCE, México, 1975.

, Haciendas and rancbos in the Mexican Bajío: León, 1700-1860, Cambridge University Press, Cambridge, 1978.

,Hacienda profits and tenant farming in the mexican Bajio" en Brading, Haciendas, 1978.

-, "La estructura de la producción agrícola en el Bajío de 1700-1850" en Brding, Haciendas, 1978.

-Carmagnani, Marcello, $\mathrm{El}$ regreso de los dioses. El proceso de reconstitución de la identidad étnica en Oaxaca. Siglo XVIr y XVIII, FCE, México, 1988.

-Cervantes Bello, Francisco Javier, "E1 declive del crédito eclesiástico en la región de Puebla, 1800-1847", en Martínez LópezCano, Iglesia, 1995.

-Chevalier, François, La formación de los latifundios en México, FCE, México, 1982.

_La gran propiedad en México desde el siglo XVI hasta comienzos del Siglo XIX" en Chevalier, La formación, 1982.

- "La hacienda, nueva unidad económica y social" en Chevolier, $L a$ formación, 1982.

-Chiaramonte, José Carlos, Formas de economía y sociedad en bispanoamérica, Enlace/Grijalbo, México, 1984.
-Coasthworth, John H., "La historiografía económica de México", Revista Económica, vol. VI, núm. 2, 1988, pp. 277-291.

-Couturier, Edith, "Una viuda aristocrática en la Nueva España del siglo XVII: la condesa de Miravalle", Historia Mexicana, vol. XLI, núm. 3, enero-marzo, 1992, pp. 327-363.

-Escandón, Patricia, "Economía y sociedad en Sonora: 1767-1821" en Ortega y del Río (coords.), Tre siglos, 1993.

-Ewald, Ursula, Estudios sobre la bacienda colonial en México: las propiedades rurales del Colegio del Espiritu Santo en Puebla, Wiesbaden, 1976.

-Farriss, Nancy, Maya society under colonial rule, Princeton University Press, Princeton, 1984.

-Figueroa Zamudio, Silvia, "Los agustinos de Michoacán frente a las reformas borbónicas. El caso de Yuriria (1753-1761)" en Virginia Guedea y Jaime Rodríguez (comps.), Cinco siglos, 1992, 2 vols.

-Flores Caballero, R., "La consolidación de vales reales en la economía, la sociedad y la política novohispanas", Historia Mexicana, vol. XVIII, núm. 3, enero-marzo de 1969, pp. 334-378.

-Florescano, Enrique (editor), Haciendas, latifundios y plantaciones en América Latina, México, 1975.

, Origen y desarrollo de los problemas agrarios de México, 1500 . 1821, ERA, México, 1976.

$\longrightarrow$, El nuevo pasado mexicano, Cal y Arena, México, 1992, 2 a ed.

$\longrightarrow$, "El problema agrario en los últimos ańos del virreinato, 1800-1821", en Menegus (comp.), Problemas, 1995.

-Frost, Elsa Cecilia, Michael C. Meyer y Josefina Z. Vázquez (comps.), El trabajo y los trabajadores en la bistoria de México, V Reunión de Historiadores Mexicanos y Norteamericanos, El Colegio de México/ University of Arizona Press, México, 1979.

-Gamboa, F. X., Comentarios a las or denanzas de minería dedicados al católi- 
co rey nuestro señor don Carlos III, Madrid, 1761.

-Garavaglia, Juan Carlos, "Atlixco el agua, los hombres y la tierra en valle mexicano (siglos XVI-XVII) en A. Tortolero, Tierra, 1997. mortización en las haciendas mexicanas: el entorno agrario de Tepeaca, 1700-1870", Siglo XIX, Revista de Historia, 1990, vol. v, núm.10, pp. 33-76.

y Juan Carlos Grosso, "Marchands, hacendados et paysans à Tepeaca. Un marché local mexicain à la fin du XVIIIe siècle", Annales, E.S.C., núm. 44, may-jun. de 1989 , pp. 553-580.

y Juan Carlos Grosso, "Mexican elites of a provincial town: the landowners of Tepeaca (1700-1870", Hispanic American Historical Review, vol. 70 , núm. 2, mayo de 1990, p. 266.

- Puebla desde una perspectiva microbistórica. Tepeaca y su entorno agrario: población, producción e intercambio (1740-1870), Editorial Claves Latinoamericanas/ Universidad Autónoma de Puebla/Universidad Nacional del Centro, México, 1994.

-Gibson, Charles, Los aztecas bajo el dominio español, 1519-1810, Siglo XXI, México, 1967.

-González Muñoz, Victoria, Cabildos y grupos de poder en Yucatán (siglo XVII), Excma. Diputación de Sevilla, Sevilla, 1994.

-Greenow, Linda L., "Spatial dimensions of the credit market in eighteenth century Nueva Galicia" en David Robinson (comp.), Social fabric and social structure in colonial Latin America, Syracuse University, Ann Arbor, 1979.

-Guedea, Virginia y Jaime E. Rodríguez (comps.), Cinco siglos de bistoria de México, Instituto Mora/University of California-Irvine, México, 1992. 2 vol.

-Hadley, Philip L., Minería y sociedad en el centro minero de Santa Eulalia, Chibuabua (1709-1750), FCE, México, 1975.
-Hamnett, Brian, "The appropriation of mexican church wealth by the spanish bourbon government: the Consolidación de Vales Reales, 1805-1809", Journal of Latin American Studies, vol. 1, núm. 2, 1969, pp. 86-87. , Roots of Insurgency. Mexican Regions 1750-1824, Cambridge University Press, Cambridge, 1986.

, "Between bourbon reforms and liberal reforms. The political economy of a mexican provine-Oaxaca, 1750-1850" en Andrien y Johnson (comps.), The political, 1994.

, "Obstáculos a la política agraria del despotismo ilustrado", en Andrien y Johnson (comps.), The political, 1994. Menegus, Problemas, 1995.

-Harris, Charles H., A mexican family empire: the latifundio of the Sánchez Navarro's 1765-1867, Austin, 1975.

-Jiménez Pelayo, Águeda, Haciendas y comunidades indigenas en el sur de Zacatecas, INAH, México, 1989.

—. "El crédito eclesiástico en Nueva España: el caso de Guadalajara", en Leonor Ludlow y Jorge Silva Riquer (comps.), Los negocios, 1993.

-Kicza, John (comp.), The indian in latin american bistory, resilience and acculturation, Scholarly Resources, Wilmington, D.E., 1993.

-Klein, Herbert S., "Las economías de Nueva España y Perú, 1680-1809: la visión a partir de las Cajas Reales", en Heraclio Bonilla (comp.), El sistema colonial en la América española, Crítica, Barcelona, 1991.

- Las finanzas americanas del imperio español, Instituto de Investigaciones Dr. José María Luis Mora/UAM, México, 1994.

-Konrad, Herman, A jesuit bacienda in colonial Mexico: Santa Lucia, 1576-1767, Stanford University Press, Stanford, 1980.

-Ladd, Doris, The mexican nobility at independence, 1780-1826, Institute of Latin American Studies, University of Texas, Austin, 1976. 
-Langue, Frédérique, "Del minero rico a la nobleza: el papel de la frontera zacatecana en la formación de una elite económica y social", Anuario de Estudios Americanos, vol. XLIV, 1987, pp. 173-193.

, "La convergencia de los intereses particulares y estatales: el alboroto de 1767 en Nueva Galicia", Temas Americanistas, Universidad de Sevilla, núm. 7 , 1990, pp. 14-17.

- "Mineros y poder en Nueva España. El caso de Zacatecas en vísperas de la independencia", Revista de Indias, núm. 192, mayo-agosto de 1991, pp. 327-341.

Mines, terres et société a Zacatecas (Mexique) de la fin du XVIIIe siècle à l'Indépendance, Publications de la Sorbonne, París, 1992 (de próxima aparición en el FCE, Los señores de Zacate. cas. Una aristocracia minera del siglo XVII novobispano).

- "Types de croissance, types de mines; le régne des "mineurs capitalistes" en Langue, Mines, 1992.

-Lavrin, Asunción, "El capital eclesiástico y las elites sociales en Nueva España a fines del siglo XVII", Mexican Studies/Estudios Mexicanos, vol. I, núm. 1, 1985, pp. 6 y ss.

-Leal, Juan Felipe y Mario Huacuja R., Economía y sistema de haciendas en México. La hacienda pulquera en el cambio, siglos XVIII, XLX y XX, ERA, México, 1982.

-Lindley, Richard B., Las baciendas y el desarrollo económico. Guadalajara, México, en la época de la independencia, FCE, México, 1987.

-Loera, Margarita, Economía campesina indígena en la colonia, INI, México, 1981.

-Lohmann Villena, Guillermo, Los americanos en las órdenes militares, C.S.I.C., Madrid, 1947, 2 vols.

-Ludlow, Leonor y Jorge Silva Riquer (comps.), Los negocios y las ganancias de la colonia al México moderno, Instituto Mora/ Instituto de Investigaciones Históricas-UNAM, Mexico, 1993.
-Marichal, Carlos, "La Iglesia y la crisis financiera del virreinato, 1780-1808". Apuntes sobre un tema viejo y nuevo", Relaciones, vol. 10, núm. 40, 1989, pp. 103-129.

-Martín, Cheryl E., Rural society in colonial Morelos, University of New Mexico Press, Albuquerque, 1985.

- "Modes of production in colonial México: the case of Morelos", Estudios de Historia Novobispana, núm. 12, 1992, pp. 107-121.

, "Modes of production in colonial México: the case of Morelos", Estudios de Historia Novobispana, núm. 12, 1992, pp. 107-121.

-Martínez López-Cano, Ma. del Pilar, Iglesia, Estado y Economía siglos XVI al $X I X$, UNAM/Instituto de Investigaciones Dr. José María Luis Mora, México, 1995.

-Medina Rubio, Arístides, La iglesia y la producción agrícola en Puebla 1540-1795, El Colegio de México, México, 1983.

-Menegus Bornemann, Margarita, "La participación indígena en los mercados del valle de Toluca a fines del periodo colonial", en Silva, Grosso y Yuste, Circuitos mercantiles, 1995.

\section{(comp.), Problemas agra-}

rios y propiedad en México, siglos XVIII y $X I X$, (introducción y selección), Centro de Estudios Históricos-El Colegio de México, México, 1995.

-Miño Grijalva, Manuel, Haciendas, Pueblos y comunidades, CNCA, México, 1991.

-Morin, Claude, Micboacán en la Nueva España del siglo XVII. Crecimiento y desigualdad en una economía colonial, FCE, México, 1979 (Col. Tierra Firme).

-Musset, Alain, "De Tlaloc Hipócrates. El agua y la organización del espacio en la cuenca de México (siglo xvi-xvII)," en Tortolero, Tierra, agua, 1997.

- Navarrete, Nicolás, Historia de la provincia agustiniana de San Nicolás de Tolentino de Michoacán, Porrúa, México, 1978, t. I.

-Nickel, Herbert, Soziale morpbologie des mexicanischen bacienda, Franz 
Steiner Verlag, Wiesbaden, 1978, 2a ed. en español, Morfología social de la bacienda mexicana, FCE, México, 1996.

-Ortega y Ricardo Pérez Gallardo, Estudios genealógicos, Imp. de Eduardo Dublán, México, 1902.

-Ortega y Sergio Ignacio del Río (coords.), Tres siglos de bistoria sonorense (1530-1830), UNAM, México, 1993.

-Ouweneel, Arij, y Cristina Torales Pacheco (comps.), Empresarios, indios y estado. Perfil de la economía mexicana (siglo XVIII), CEDLA, Amsterdam, 1988 (Latin American Studies, 45).

- Catrien Bijleveld, C.H.J., "The economic cycle in Bourbon Central Mexico: a critique of the recaudación del diezmo liquido en pesos", Hispanic American Historical Review, vol. 69, núm. 3, 1989 , pp. 479-557.

-Pastor, Rodolfo, Campesinos y reformas: la Mixteca, 1700-1856, El Colegio de México, México, 1987.

, et al., Fluctuaciones económicas en Oaxaca durante el siglo XVIII, El Colegio de México, México, 1979.

-Payno, Manuel, Los Bandidos de Río Frío, Porrúa, México, 1945.

-Pérez Herrero, Pedro, Región e bistoria en México (1700-1850). Métodos de análisis regional, Instituto Mora/Universidad Autónoma Metropolitana, México, 1991.

-Pescador, Juan Javier, De bautizados a fieles difuntos. Familia y mentalidades en una parroquia urbana: Santa Catarina de México, 1568-1820, El Colegio de México, México, 1992.

-Pitt-Rivers, Julián, Antbropologie de l'bonneur. La mésaventure de Sichem, Le Sycomore, París, 1983 (Cambridge University Press, 1977).

-Riley, James D., Hacendados jesuitas en México. El Colegio Máximo de San Pedro y San Pablo (1685-1767), SEP, México, 1976.

-Rubial García, Antonio, El convento agustino y la sociedad novosbipana (1533-1630), UNAM, México, 1989.
-Sánchez Maldonado, María Isabel, "La capellanía en la economía de Michoacán en el siglo XVII", en Martínez López-Cano, Iglesia, 1995.

-Sanchiz Ochoa, Pilar, Los bidalgos de Guatemala. Realidad y apariencia en un sistema de valores, Universidad de Sevilla/Seminario de Antropología Americana, Sevilla, 1976.

-Scharrer, Beatriz, "Trabajadores y cambios tecnológicos en las urgencias (siglo XVIIXVIII)", en G. Artis Espriu et al, Trabajo, 1992.

-Serrera Contreras, Ramón María, Guadalajara ganadera Estudio regional novobispano 1760-1805, Escuela de Estudios Hispanoamericanos, Sevilla, 1977.

Tráfico terrestre y red vial en las indias españolas, Ministerio del Interior/Dirección General de Tráfico/Lunwerg Editores, Madrid-Barcelona, 1992.

-Silva Riquer, Jorge, "La consolidación de vales reales en el obispado de Michoacán, 1804-1809", en Virgina Guedea y Jaime Rodríguez, Cinco siglos de bistoria de México, 1992, vol. 2.

- Juan Carlos Grosso y Carmen Yuste (comps.), Circuitos mercantiles $y$ mercados en Latinoamérica. Siglos XVIII$X I X$, Instituto de Investigaciones Dr. José María Luis Mora/IIH-UNAM, México, 1995.

-Taylor, William B., Landlords and peasants in colonial Oaxaca, Stanford University Press, Stanford, 1972.

- Drinking, bomicide and rebellion (Stanford University Press, 1979), versión en esp. Embriaguez, homicidio y rebelión en las poblaciones coloniales mexicanas, FCE, México, 1987.

-Tortolero Villaseñor, Alejandro, "La hacienda mexicana: nuevos problemas, métodos y fuentes", Iztapalapa, núm. 36, enero-junio de 1995, pp. 145-166.

ambiente en México: estado de la cuestión", Noticiario de Historia Agraria-Universidad de Murcia, núm. 11, enero-junio de 1996, pp. 151-178. 
(coord.), Tierra, agua y bosques: bistoria y medio ambiente en el México central, CIESAS, México, 1997.

-Tovar Pinzón, Hermés, "Elementos constitutivos de la empresa jesuita en la segunda mitad del siglo XVIII en México" en Enrique Florescano, (comp.), Haciendas, 1975.

-Trabulse, Elias (coord.), Fluctuaciones económicas en Oaxaca durante el siglo XVIII, El Colegio de México, México, 1979.

-Tutino, John, "Hacienda social relation in Mexico: the Chalco region in the era of Independence", Hispanic American Historical Riview, vol. 55, núm. 3, 1975, pp. 497-528.

"Provincial spaniard indian towns and haciendas. Interrelated sectors of agrarian society in the valleys of Mexico and Toluca, 1750-1810", en Ida Altman y John Lockhart (comp.), Provinces, 1976.

, "Creole Mexico: spanish elites, haciendas and indians towns, 1750$1810 "$ ", tesis de doctorado, University of Texas, Austin, 1976 (University Microfilms International, Ann Harbor, 1978).

-, "Life and labor in north mexican haciendas": the Querétaro-San Luis Potosi Region, 1775-1810", en Frost, Meyer y Vazquéz. (comps.), El trabajo, 1979.

- "Los españoles de las provincias. Los pueblos de indios y las haciendas: sectores interrelacionados de la socieclad agraria en los valles de México y Toluca, 1750-1810", en Manuel Miño Grijalva, Haciendas, 1991.

- "Historias del México agrario", Historia Mexicana, vol. XLII, núm. 166 , oct.-dic. 1992 , pp. 177 y ss.

-Vargas-Lobsinger, María, Formación y decadencia de una fortuna. Los mayorazgos de San Miguel del Aguayo y de San Pedro del Álamo, 1583-1823, UNAM, México, 1992.

-Wobeser, Gisela von, La bacienda de San Carlos Borromeo, UNAM, México, 1980.

-_La bacienda azucarera en la época colonial, SEP/UNAM, México, 1988.
"Mecanismos crediticios en la Nueva España: el uso del censo consignativo", Mexican Studies/Estudios Mexicanos, vol. 5 , núm. 1, invierno de 1989, pp. 1-23.

El crédito eclesiástico en la Nueva España siglo XVII, UNAM, México, 1994.

Young, Eric van, Hacienda and market in eighteenth century Mexico. The rural economy of the Guadalajara region (1675-1743), University of California Press, Berkeley, 1981.

- "Mexican rural history since Chevalier. 'The historiography of the colonial hacienda", Latin American Researcb Review, vol. XVIII, núm. 3, 1983, pp. 5-61. La ciudad y el campo en el México del siglo XVII: la economía rural de la región de Guadalajara, 1675-1820, FCE, México, 1989.

- "Haciendo historia regional, consideraciones metodológicas y teóricas" en Pérez Herrero, Región, 1991. "Historia rural desde Chevalier: historiografia de la hacienda colonial", en E. van Young, La crisis, 1992.

- "La crisis del orden colonial. Estructura agraria y rebeliones populares de la Nueva España, 1750-1821, Alianza Editorial, México, 1992.

—_La era de la paradoja: la agricultura mexicana a fines del periodo colonial (1750-1810)" en E. van Young, $\mathbf{L a}$ crisis, 1992.

$\longrightarrow$ "Hacia la revuelta: orígenes agrarios de la rebelión de Hidalgo en la región de Guadalajara" en van Young, La crisis, 1992.

- "Hinterland y mercado urbano: el caso de Guadalajara y su región" en Young, La crisis, 1992.

ricos y los pobres más pobres: salarios más les y estandores populares de vida a fines de la colonia en México" en van Young, La crisis, 1992. 